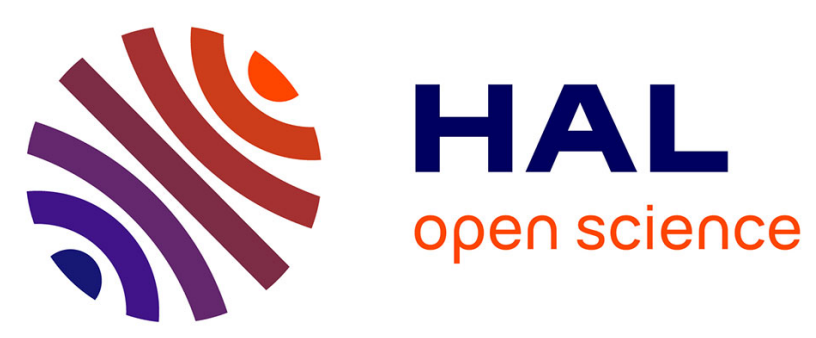

\title{
Amphibole as an archivist of magmatic crystallization conditions: problems, potential, and implications for inferring magma storage prior to the paroxysmal 2010 eruption of Mount Merapi, Indonesia
}

Saskia Erdmann, Caroline Martel, Michel Pichavant, Alexandra Roma Larisa

Kushnir

\section{To cite this version:}

Saskia Erdmann, Caroline Martel, Michel Pichavant, Alexandra Roma Larisa Kushnir. Amphibole as an archivist of magmatic crystallization conditions: problems, potential, and implications for inferring magma storage prior to the paroxysmal 2010 eruption of Mount Merapi, Indonesia. Contributions to Mineralogy and Petrology, 2014, 167, pp.1-23. 10.1007/s00410-014-1016-4 . insu-01002350

\section{HAL Id: insu-01002350 \\ https://hal-insu.archives-ouvertes.fr/insu-01002350}

Submitted on 20 Jun 2014

HAL is a multi-disciplinary open access archive for the deposit and dissemination of scientific research documents, whether they are published or not. The documents may come from teaching and research institutions in France or abroad, or from public or private research centers.
L'archive ouverte pluridisciplinaire HAL, est destinée au dépôt et à la diffusion de documents scientifiques de niveau recherche, publiés ou non, émanant des établissements d'enseignement et de recherche français ou étrangers, des laboratoires publics ou privés. 
Amphibole as an archivist of magmatic crystallization conditions:

problems, potential, and implications for inferring magma storage

prior to the paroxysmal 2010 eruption of Mount Merapi, Indonesia

Saskia Erdmann*, Caroline Martel, Michel Pichavant, Alexandra Kushnir

Université d'Orléans - CNRS/INSU - ISTO - BRGM, UMR 7327

1A Rue de la Férollerie, 45071 Orléans, France

*Corresponding author: serdmann@dal.ca; phone: +33-02 38255383 


\section{ABSTRACT}

Amphibole is widely employed to calculate crystallization temperature and pressure, although its potential as a geobarometer has always been debated. Recently, Ridolfi et al. (2010) and Ridolfi and Renzulli (2012) have presented calibrations for calculating temperature, pressure, $f \mathrm{O}_{2}$, melt $\mathrm{H}_{2} \mathrm{O}$, and melt major and minor oxide composition from amphibole with a large compositional range. Using their calibrations, we have: (i) calculated crystallization conditions for amphibole from eleven published experimental studies to examine problems and the potential of the new calibrations; and (ii) calculated crystallization conditions for amphibole from basaltic-andesitic pyroclasts erupted during the paroxysmal 2010 eruption of Mount Merapi in Java, Indonesia, to infer pre-eruptive conditions. Our comparison of experimental and calculated values shows that calculated crystallization temperatures are reasonable estimates. Calculated $f \mathrm{O}_{2}$ and melt $\mathrm{SiO}_{2}$ content yield potentially useful estimates at moderately reduced to moderately oxidized conditions and intermediate to felsic melt compositions. However, calculated crystallization pressure and melt $\mathrm{H}_{2} \mathrm{O}$ content are untenable estimates that largely reflect compositional variation of the crystallizing magmas and crystallization temperature and not the calculated parameters. Amphibole from Merapi's pyroclasts yields calculated conditions of $\sim 200-800 \mathrm{MPa}, \sim 900-1050{ }^{\circ} \mathrm{C}, \sim \mathrm{NNO}+0.3-$ $\mathrm{NNO}+1.1, \sim 3.7-7.2$ wt $\%$ melt $\mathrm{H}_{2} \mathrm{O}$, and $\sim 58-71$ wt $\%$ melt $\mathrm{SiO}_{2}$. We interpret the variations in calculated temperature, $f \mathrm{O}_{2}$, and melt $\mathrm{SiO}_{2}$ content as reasonable estimates, but conclude that the large calculated pressure variation for amphibole from Merapi and many other arc volcanoes is evidence for thorough mixing of mafic to felsic magmas and not necessarily evidence for crystallization over a large depth range. In contrast, bimodal pressure estimates obtained for other arc magmas reflect amphibole crystallization from mafic and more evolved magmas, respectively, and should not necessarily be taken as evidence for crystallization in two reservoirs at variable depth.

Keywords: amphibole; chemometer; barometer; thermometer; magma mixing; Merapi 


\section{INTRODUCTION}

Amphibole is a characteristic phase of mafic to felsic hydrous magmas (Arculus and Wills 1980; Cawthorn et al. 1973; Davidson et al. 2007). Its textures and composition have been utilized to qualitatively and quantitatively infer magmatic processes and intensive parameters of crystallization (De Angelis et al. 2013; Bachmann and Dungan 2002; Ridolfi et al. 2008, 2010; Rutherford and Devine 2008; Shane and Smith 2013; Thornber et al. 2008; Turner et al. 2013). Most commonly, amphibole is used to infer magmatic crystallization pressure and temperature. Its use as a geothermometer is generally accepted, while its potential as a geobarometer is often limited and continues to be debated (e.g., Bachmann and Dungan 2002; Barnes 1987; Holland and Blundy 1990; Rutherford and Devine 2003; Shane and Smith 2013).

Amphibole-plagioclase thermometry is calibrated for the $\mathrm{Si}-\mathrm{Na}$-Al-Ca composition of equilibrium pairs with crystallization temperatures of up to $\sim 1000{ }^{\circ} \mathrm{C}$, producing relatively pressureinsensitive estimates $\left( \pm 72{ }^{\circ} \mathrm{C} / \mathrm{GPa}\right.$; Blundy and Cashman 2008; Blundy and Holland 1990; Holland and Blundy 1994). Early amphibole barometers were calibrated for the total Al content of amphibole, crustal to upper mantle pressures, and limited temperature intervals (for $<750{ }^{\circ} \mathrm{C}$ : Hammarstrom and Zen 1986; Hollister et al. 1987; Schmidt 1992; for $\sim 750{ }^{\circ} \mathrm{C}$ : Johnson and Rutherford 1989; Thomas and Ernst 1990). To account for effects of magma composition and $f \mathrm{O}_{2}$ variations on amphibole composition, thermobarometers were recommended for defined, multi-phase assemblages and restricted compositions. Anderson and Smith (1995) later presented an amphibole barometer that corrects for crystallization temperature, as temperature strongly affects amphibole $\mathrm{Si}$-Al composition and, thus, pressure estimates (e.g., Hammarstrom and Zen 1992; Holland and Blundy 1990).

Recently, Ridolfi et al. (2010) and Ridolfi and Renzulli (2012) have published thermobarometric and chemometric equations for estimating temperature, pressure, $f \mathrm{O}_{2}, \mathrm{melt}_{\mathrm{H}} \mathrm{O}$, and melt major oxide components from amphibole composition alone (hereafter referred to as the 
calibrations of R2010 and RR2012). Their calibrations are recommended for amphibole crystallized from calc-alkaline to alkaline magmas, at mantle and lower to upper crustal pressures, near-liquidus to near-solidus temperatures of mafic to intermediate magmas, moderately reduced to moderately oxidized, and $\mathrm{H}_{2} \mathrm{O}$-poor to $\mathrm{H}_{2} \mathrm{O}$-rich conditions. The formulations of $\mathrm{R} 2010$ and $\mathrm{RR} 2012$ differ in detail, but they all use amphibole $\mathrm{Si}, \mathrm{Ti}, \mathrm{Al}, \mathrm{Fe}, \mathrm{Mg}, \mathrm{Ca}, \mathrm{Na}$, and $\mathrm{K}$ concentrations for calculating the dependent variables (Table 1). Owing to their large range of possible application and ease of use, they have already been widely applied (e.g., Fig. 1).

Most studies consider crystallization conditions calculated with the R2010 and RR2012 calibrations as reliable. However, few studies have pointed out systematic problems (e.g., no account for the influence of magma/melt composition) and/or discrepancies between crystallization conditions estimated from amphibole composition and other methods (e.g., Bachmann et al. 2011; De Angelis et al. 2013; Shane and Smith 2013). To evaluate the extent of problems, but also the potential in employing the R2010 and RR2012 thermobarometric and chemometric equations, we have (i) examined crystallization conditions calculated for amphibole from eleven published experimental studies with basaltic to dacitic compositions; and (ii) characterized crystallization conditions recorded by amphibole from basaltic-andesitic pyroclasts erupted at Mount Merapi in 2010. We first present our evaluation of the experimental data and then proceed to our perusal of amphibole in the natural samples, discussing each dataset separately.

\section{SAMPLES AND METHODS}

The experimental studies examined include crystallization experiments with basaltic to evolved dacitic starting materials. They were run at $800-1000{ }^{\circ} \mathrm{C}$, an $f \mathrm{O}_{2}$ of NNO-0.6 to NNO+1.4, and $\mathrm{H}_{2} \mathrm{O}-$ saturated to $\mathrm{H}_{2} \mathrm{O}$-undersaturated conditions (Table 2). Experimental pressure was close to 200 or 400 $\mathrm{MPa}$. The studies were selected on the basis of their range in starting material composition and their 
low to moderate crystallization pressure. Data were evaluated for a selected subset of experiments for which amphibole and host glass analyses are reported in the original studies. Amphibole compositions from several of the selected experimental studies with felsic to intermediate starting materials were also used in the R2010 and/or RR2012 calibrations (Table 2). However, R2010 and RR2012 have exclusively used amphibole crystallized from intermediate to mafic starting materials in experiments performed at $\geq 395 \mathrm{MPa}$ and predominantly $\geq 700 \mathrm{MPa}$ (Appendix Table of R2010; Table 2 of RR2012; including basanite to basaltic-andesitic compositions). We point out that a full evaluation of pressure versus compositional effects on crystallizing high-Al, low-Si amphibole also requires the evaluation of amphibole crystallized from mafic compositions at low pressure. In addition to the datasets employed by R2010 and RR2012 our selected database therefore includes three studies performed on basaltic to Mg-rich andesitic starting materials crystallized at low pressure, i.e. at $200 \mathrm{MPa}$ (Sisson and Grove 1994; Grove et al. 2003; Barclay and Carmichael 2004).

The R2010 and RR2012 calibrations have employed amphibole and glass compositions from equilibrium crystallization experiments for which mass balance calculations on run products show low residuals $\left(\Sigma \mathrm{R}^{2}<2\right)$. Only amphibole analyses with low standard deviations that yield stochiometric formulas were selected (Appendix of R2010; average and maximum percentage standard deviation values are 1.0 and 1.9 for $\mathrm{SiO}_{2} ; 6.8$ and 20 for $\mathrm{TiO}_{2} ; 2.9$ and 7.4 for $\mathrm{Al}_{2} \mathrm{O}_{3} ; 3.9$ and 6.9 for $\mathrm{FeO} ; 30$ and 114 for $\mathrm{MnO} ; 2.6$ and 8.5 for $\mathrm{MgO} ; 2.3$ and 5.6 for $\mathrm{CaO} ; 4.1$ and 11 for $\mathrm{Na}_{2} \mathrm{O} ; 8.1$ and 27 for $\mathrm{K}_{2} \mathrm{O}$ ). The $\mathrm{R} 2010$ calibration requires amphibole compositions with $\mathrm{Al} \#={ }^{[6]} \mathrm{Al} / \mathrm{Al}_{\text {total }}$ of $\leq 0.21$; the $\mathrm{RR} 2012$ calibration is suggested for a wide range of compositions, but amphibole compositions should plot within the compositional fields of Figure 1 of RR2012 (our Fig. 2). Amphibole hosted in high- $\mathrm{H}_{2} \mathrm{O}$ experimental glasses was considered problematic. Quench crystals and microlites as well as "vein-type" amphibole (crystallized by fluid-rock reaction) and suspected xenocrysts are excluded from their database. 
For our evaluation, we have selected (i) studies that report a close approach to experimental equilibrium; (ii) amphibole compositions from experiments in which reported phase proportions calculated by mass balance have low residual squares $\left(\Sigma \mathrm{R}^{2}\right) \leq 1.8$; (iii) amphibole with approximately stochiometric composition, original totals of 95.6-98.8 wt\%, and recalculated totals of 98.1-101.7 wt\% (including estimates for $\mathrm{Fe}_{2} \mathrm{O}_{3}$ and $\mathrm{H}_{2} \mathrm{O}$; Electronic Appendix); and (iii) amphibole compositions with relatively low standard deviations (average and maximum percentage standard variation values are 1.2 and 2.6 for $\mathrm{SiO}_{2} ; 7.8$ and 20 for $\mathrm{TiO}_{2} ; 3.4$ and 7.5 for $\mathrm{Al}_{2} \mathrm{O}_{3} ; 4.1$ and 8.7 for $\mathrm{FeO} ; 27$ and 94 for $\mathrm{MnO} ; 3.0$ and 7.4 for $\mathrm{MgO} ; 2.1$ and 5.3 for $\mathrm{CaO} ; 3.8$ and 11 for $\mathrm{Na}_{2} \mathrm{O} ; 8.9$ and 21 for $\mathrm{K}_{2} \mathrm{O}$; these values are close to those reported by RR2012, but maximum values are exceeded by six amphibole compositions in $\mathrm{SiO}_{2}$ or $\mathrm{Al}_{2} \mathrm{O}_{3}$ as indicated in Table 2 and summarized in the Electronic Appendix). All amphibole compositions except one classify as "consistent" according to the scheme of $\mathrm{R} 2010$ (i.e with $\mathrm{Al} \#={ }^{[6]} \mathrm{Al} / \mathrm{Al}_{\text {total }} \leq 0.21$; Hab7 amphibole of Pichavant et al. 2002 has $\mathrm{Al} \#=0.22$ ). Nearly all amphibole compositions also plot inside the compositional fields of amphibole used for the RR2012 calibration (Fig. 2); the few amphibole compositions outside the recommended fields have slightly elevated $\mathrm{Na}, \mathrm{R}^{2+}$, and $\mathrm{Mg}$ contents (Fig. 2a,c,e,f). Compositions of amphibole quench crystals are not included in our study. Amphibole crystallized at high- $\mathrm{H}_{2} \mathrm{O}$ conditions, however, was not considered problematic for the evaluated low-pressure experiments. In fact, high melt $\mathrm{H}_{2} \mathrm{O}$ and $\mathrm{Na}_{2} \mathrm{O}$ contents are a pre-requisite for near-liquidus/high-temperature amphibole crystallization from mafic starting materials (e.g., Sisson and Grove 1992).

Our samples from Merapi include juvenile dome clasts and pumice samples erupted November $5^{\text {th }}$ and $6^{\text {th }}, 2010$. All samples were collected in 2013 along Kali Gendol and near the tourist site at Mariam Bunker. Amphibole textures were observed in the field and characterized in 30 thin sections (Table 3). Amphibole microtextures and reaction rims were imaged in backscatter mode and qualitatively analyzed by secondary electron microprobe. Electron microprobe analyses were acquired for amphibole from eight selected samples using a Cameca SX5 electron microprobe at the 
CNRS-BRGM-Université d'Orléans. They were performed with a focussed beam at $15 \mathrm{keV}$ and 10 nA. Spot analyses were collected for all or up to forty crystals of a thin section, complemented by compositional core-rim profiles for selected crystals. Zoning is described as normal for rim-ward increasing $\mathrm{SiO}_{2}$ and decreasing calculated temperature and pressure. Reverse zoning is characterized by rim-ward decreasing $\mathrm{SiO}_{2}$ and increasing calculated temperature and pressure.

To determine amphibole stochiometry and nomenclature we have used the Leake et al. (1997) classification scheme and the Amp-TB.xls spreadsheet provided by R2010. For calculating amphibole crystallization conditions - temperature, pressure, $f \mathrm{O}_{2}$, melt $\mathrm{H}_{2} \mathrm{O}$ and melt $\mathrm{SiO}_{2}$ contents we have employed (i) the Amp-TB.xls spreadsheet of R2010; and (ii) a selection of equations published by RR2012 (Table 1). Amphibole element concentrations that most prominently control the calculated variables are: (i) $\mathrm{Si}$ and $\mathrm{Al}$ for temperature; (ii) $\mathrm{Si}$ and/or $\mathrm{Al}$ for pressure; (iii) $\mathrm{Si}$ and/or $\mathrm{Mg}$ for $\mathrm{fO}_{2}$; (iv) $\mathrm{Si}$ and $\mathrm{Al}$ for melt $\mathrm{H}_{2} \mathrm{O}$; and (v) $\mathrm{Si}$ and $\mathrm{Mg}$ for melt $\mathrm{SiO}_{2}$ contents. Temperature, melt $\mathrm{H}_{2} \mathrm{O}$, and melt $\mathrm{SiO}_{2}$ contents calculated with the RR2012 equations also depend on the calculated crystallization pressure.

To calculate amphibole crystallization pressure, RR2012 have provided five equations (equations 1a to 1e). They recommend that pressure is first calculated with all five equations and that a complex empirical procedure is then used to select case-by-case the most appropriate values (RR2012, page 891). Most important for our application is that the five equations are calibrated for different pressure ranges and that they have variable uncertainties. Equations $1 \mathrm{~b}$ and $1 \mathrm{c}$ are calibrated for low pressure ( 130-500 MPa), while Figure 5e of RR2012 indicates that both equations perform well up to crystallization pressures of $<900 \mathrm{MPa}$. Equations $1 \mathrm{~b}$ and $1 \mathrm{c}$ are thus most appropriate for our evaluation of amphibole crystallized in the published $\sim 200$ and $\sim 400 \mathrm{MPa}$ experiments. Additionally, the two equations have low average standard and maximum errors of 37 and $43 \mathrm{MPa}$ and 69 and $116 \mathrm{MPa}$, respectively. In contrast, equations 1a, 1d, and 1e are calibrated for 130 to 
$2200 \mathrm{MPa}, 400$ to $1500 \mathrm{MPa}$, and 930 to $2200 \mathrm{MPa}$, and they have higher average standard and maximum errors of $\sim 141$ to $175 \mathrm{MPa}$ and 377 to $540 \mathrm{MPa}$.

We have calculated amphibole crystallization pressure with all five equations as reported in the Electronic Appendix. However, we have not followed the recommended approach for selecting the most appropriate pressure value because (i) amphibole compositions from several of the lowpressure experimental studies suggested the use of equations $1 \mathrm{~d}$ and $1 \mathrm{e}$ that are calibrated for high pressures ( $\geq 400$ and $930 \mathrm{MPa}$ ); and (ii) it seemed inconsistent to us to compare a dataset calculated with variable methods. We have therefore decided to report average values calculated with equations $1 \mathrm{~b}$ and $1 \mathrm{c}$, which are calibrated for the considered experimental pressure range. As a result, some calculated pressure values differ more significantly from the known experimental values than the values determined with the recommended procedure. In other cases our approach improved the accuracy of the estimate. It is important to note that our approach improved several calculated values by $>200 \mathrm{MPa}$ as compared to the recommended values, whereas the discrepancy between our and the recommended pressure estimate is always $\leq 32 \mathrm{MPa}$ (and typically $<10 \mathrm{MPa}$; all calculated values are reported in the Electronic Appendix).

For the experimental studies considered, we present calculated amphibole crystallization conditions for both the R2010 and RR2012 calibrations in text and figures (Table 2; Figs 3 to 7). We compare experimental and calculated values and examine correlations between amphibole compositions and calculated variables. For the Merapi amphibole dataset, we chose to present only one dataset for clarity and brevity. In text and figures, we present values calculated using the R2010 calibration. Table 4 also summarizes values calculated from the average results of equations $1 \mathrm{~b}$ and 1c of RR2012. We settled on this presentation to equally treat the published experimental dataset and our dataset on amphibole from the natural samples. An earlier study of amphibole from the 2010 Merapi pyroclasts has also inferred that most crystallization took place at pressures of $\leq 800 \mathrm{MPa}$ (Costa et al. 2013), for which RR2012 equations 1b and 1c seem to perform well (according to Fig. 
5e of RR2012). We also found that the R2010 equations yield more reliable estimates (i) for $f \mathrm{O}_{2}$ and (ii) for low- $\mathrm{SiO}_{2}$ amphibole in general. Moreover, most published studies have employed the R2010 calibration (e.g., Fig. 1), therefore facilitating data comparison.

Reported standard errors for the R2010 calibration are $\pm 14 \%$ at $<450 \mathrm{MPa}$ and up to $33 \%$ at $1 \mathrm{GPa}, \pm 22{ }^{\circ} \mathrm{C}$ for temperature, $\pm 0.41 \mathrm{wt} \%$ for melt $\mathrm{H}_{2} \mathrm{O}$, and $\pm 0.22 \log$ units for $f \mathrm{O}_{2}$. Reported standard errors for the RR2012 calibration are $\pm 11.5 \%$ for pressure, $\pm 23.5{ }^{\circ} \mathrm{C}, \pm 0.78 \mathrm{wt} \%$ for melt $\mathrm{H}_{2} \mathrm{O}, 1.25 \mathrm{wt} \%$ for melt $\mathrm{SiO}_{2}$, and $\pm 0.37 \log$ units for $\mathrm{fO}_{2}$. However, reported maximum errors of the R2010 and RR2012 calibrations are significantly larger: (i) 25\% of the calculated pressure value, 57 ${ }^{\circ} \mathrm{C}$, and $0.41 \log$ units for $f \mathrm{O}_{2}$ and (ii) 69 and $116 \mathrm{MPa}$ for equations $1 \mathrm{~b}$ and $1 \mathrm{c}, 50{ }^{\circ} \mathrm{C}, 2.1 \mathrm{wt} \% \mathrm{H}_{2} \mathrm{O}$, $3.0 \mathrm{wt} \% \mathrm{SiO}_{2}$, and $0.76 \log$ units for $f \mathrm{O}_{2}$. Ridolfi and Renzulli (2012) recommend their calibration for amphibole crystallized from calc-alkaline and alkaline magmas at $\sim 800-1130{ }^{\circ} \mathrm{C}, 130-2200 \mathrm{MPa}$, an $f \mathrm{O}_{2}$ of NNO-2.1 to NNNO+3.6, melt $\mathrm{H}_{2} \mathrm{O}$ contents between $\sim 2.8$ and 12.2 wt $\%$, and melt $^{\mathrm{SiO}_{2}}$ contents of $\sim 52.6-78.1 \mathrm{wt} \%$ (their Fig. 3). They also tested the R2010 calibration against their larger dataset, concluding that the older equations calculate: (i) temperatures with low errors compared to other thermometers; (ii) pressure with large errors at $\geq 1 \mathrm{GPa}$, but relatively low errors of $\leq \pm 44 \mathrm{MPa}$ for upper-crustal pressures of $\leq 500 \mathrm{MPa}$; and (iii) reasonable $f \mathrm{O}_{2}$ estimates at moderately reduced to moderately oxidized conditions, but overestimates at $<\mathrm{NNO}-1$ and underestimates at $>\mathrm{NNO}+2$.

\section{PUBLISHED CRYSTALLIZATION EXPERIMENTS}

\section{Results: Calculated T-P-fO $\mathrm{O}_{2}$-melt $\mathrm{H}_{2} \mathrm{O}$ and $\mathrm{SiO}_{2}$}

The selected experiments with basaltic to evolved dacitic starting materials contain amphibole with magnesiohastingsite, tschermakitic pargasite, and magnesiohornblende composition. Co-existing glasses are basaltic to rhyolitic in composition (Table 2). Mafic starting materials and high crystallization temperatures yield $\mathrm{SiO}_{2}$-poor amphibole in equilibrium with $\mathrm{SiO}_{2}$-poor glass. Felsic 
starting materials and low temperatures yield $\mathrm{SiO}_{2}$-rich amphibole in equilibrium with $\mathrm{SiO}_{2}$-rich glass. Amphibole abundance ranges from minor amounts to $\sim 34 \mathrm{wt} \%$. Co-existing assemblages range from olivine, clinopyroxene, magnetite, and plagioclase in mafic crystallization experiments to plagioclase, orthopyroxene, clinopyroxene, magnetite, ilmenite, and quartz in felsic crystallization experiments.

\section{Crystallization temperature}

Temperatures of the selected experiments ranged from 800 to $1000{ }^{\circ} \mathrm{C}$, while calculated temperatures vary between $\sim 820$ and $1035{ }^{\circ} \mathrm{C}$ using the R2010 calibration and between $\sim 815$ and $1125{ }^{\circ} \mathrm{C}$ using the RR2012 calibration for calculations (Fig. 3a; Table 2). Both experimental and calculated temperatures decrease with increasing amphibole $\mathrm{SiO}_{2}$ and decreasing amphibole $\mathrm{Al}_{2} \mathrm{O}_{3}$ contents (Fig. 4). The experimental and calculated temperatures correlate reasonably well for most experiments, although they commonly deviate by $\geq 50{ }^{\circ} \mathrm{C}$ (Fig. 3a; Table 2). However, significant temperature overestimates of up to $\sim 50-165{ }^{\circ} \mathrm{C}$ are calculated for amphibole characterized by relatively low $\mathrm{SiO}_{2} / \mathrm{Al}_{2} \mathrm{O}_{3}$ contents (e.g., from experiments of Martel et al. 2013; Pietranik et al. 2009; Sisson and Grove 1992). Moreover, temperature estimates differ significantly for amphibole crystallized in experiments with the same temperature but variable $\mathrm{H}_{2} \mathrm{O}$ contents, where calculated temperature systematically increases with melt $\mathrm{H}_{2} \mathrm{O}$ content (e.g., by $\sim 30-45{ }^{\circ} \mathrm{C}$ from $\mathrm{Hab} 12$ to Hab11 of Pichavant et al. 2002; Table 2).

\section{Crystallization pressure}

The pressure of the selected studies was close to 200 or $400 \mathrm{MPa}$ (Fig. 3b; Table 2). The calculated pressure values of the $200 \mathrm{MPa}$ experiments range between $\sim 120$ and $640 \mathrm{MPa}$ and $\sim 160$ and 560 MPa using the R2010 and the RR2012 calibrations, respectively. The calculated pressure values of the $400 \mathrm{MPa}$ experiments range between 200 and $480 \mathrm{MPa}$ and $\sim 190$ and $490 \mathrm{MPa}$ using the R2010 
and the RR2012 calibrations, respectively. The experimental and calculated pressure values show no correlation (Fig. 3b). Moreover, $\mathrm{SiO}_{2}$ and $\mathrm{Al}_{2} \mathrm{O}_{3}$ contents of experimental amphibole are largely uncorrelated with crystallization pressure (Fig. 5a,b), while calculated pressure values strongly decrease with amphibole $\mathrm{SiO}_{2}$ and increase with its $\mathrm{Al}_{2} \mathrm{O}_{3}$ content (Fig. 5c,d). Experiments with felsic starting materials and $\mathrm{SiO}_{2}$-rich amphibole in equilibrium with dacitic to rhyolitic glass yield calculated pressures of $\sim 200 \mathrm{MPa}$, regardless of the experimental pressure (Fig. 5c,d; Table 2; experiments of Bogaerts et al. 2006; Costa et al. 2004; Rutherford and Devine 2003; Sato et al. 2005; Scaillet and Evans 1999). Experiments with intermediate to mafic starting materials and $\mathrm{SiO}_{2}$-poor amphibole in equilibrium with andesitic melts yield calculated pressures of $~ 400-600 \mathrm{MPa}$, also independent of the experimental pressure (Fig. 5c,d; Table 2; experiments of Barclay and Carmichael 2004; Pichavant et al. 2002; Sisson and Grove 1992). For the selected studies, every 1 wt $\%$ decrease in amphibole $\mathrm{SiO}_{2}$ (and increase in its $\mathrm{Al}_{2} \mathrm{O}_{3}$ ) yields an increase of $>60 \mathrm{MPa}$ in calculated pressure.

\section{Crystallization $\mathrm{fO}_{2}$}

The reported experimental $f \mathrm{O}_{2}$ conditions range between $\sim \mathrm{NNO}-0.6$ and NNO+1.4 (Fig. 3c; Table 2). Calculated $f \mathrm{O}_{2}$ values using the $\mathrm{R} 2010$ calibration vary between $\sim \mathrm{NNO}$ and $\mathrm{NNO}+1.9$, correlating reasonably well with most experimental values (Table 2). In contrast, $f \mathrm{O}_{2}$ values calculated using the RR2012 calibration show a large range from NNO-1.8 to NNO+5.2 (Fig. 3c; Table 2). The reported experimental $f \mathrm{O}_{2}$ values and those calculated with the $\mathrm{R} 2010$ calibration show a weak increase with amphibole $\mathrm{X}_{\mathrm{Mg}}$, and a weak decrease with amphibole $\mathrm{TiO}_{2}$. Values calculated with the RR2012 equation show a strong increase with amphibole $\mathrm{X}_{\mathrm{Mg}}$, and a scattered increase with amphibole $\mathrm{TiO}_{2}$ (Table 2; Electronic Appendix). Experimental $\mathrm{fO}_{2}$ and amphibole $\mathrm{SiO}_{2}$ are uncorrelated, while calculated values and amphibole $\mathrm{SiO}_{2}$ show positive and negative correlations for estimates using the R2010 and RR2012 calibrations. 


\section{Melt $\mathrm{H}_{2} \mathrm{O}$ content}

The experimental glass $\mathrm{H}_{2} \mathrm{O}$ contents estimated by difference range between $\sim 4$ and 8 wt\% (Fig. 3d; Table 2). The melt $\mathrm{H}_{2} \mathrm{O}$ contents calculated with the R2010 and RR2012 calibrations are close in range with estimated $\sim 3$ and $8 \mathrm{wt} \%$, but they are largely uncorrelated with the experimental values (e.g., they are high for Sisson and Grove 1992's experiments and low for Pietranik et al. 2009's experiments; Fig. 3d; Table 2). Experimental glass $\mathrm{H}_{2} \mathrm{O}$ contents estimated by more sophisticated methods (e.g., Karl-Fischer titration or modified by-difference) and calculated melt $\mathrm{H}_{2} \mathrm{O}$ contents agree more closely, but they also show a weak correlation (Fig. 3e; Table 2). We also note that the data of Costa et al. (2004) and Pichavant et al. (2002) that show a nearly perfect correlation for estimated and calculated melt $\mathrm{H}_{2} \mathrm{O}$ contents were used in the R2010 and RR2012 calibrations. For $\mathrm{H}_{2} \mathrm{O}$-saturated experiments, the experimental glass $\mathrm{H}_{2} \mathrm{O}$ contents increase from the 200 to $400 \mathrm{MPa}$ experiments and from mafic, high-temperature to felsic, low-temperature experiments (Table 2; Electronic Appendix; note that our sample set for $400 \mathrm{MPa}$ is limited to data from Pichavant et al. 2002). The calculated melt $\mathrm{H}_{2} \mathrm{O}$ contents also increase from 200 to $400 \mathrm{MPa}$ experiments. However, the calculated $\mathrm{H}_{2} \mathrm{O}$ values tend to increase from felsic, low-temperature to mafic, high-temperature experiments, and are also notably low for alkaline and alkali-rich amphibole and starting material compositions (e.g., experiments from Barclay and Carmichael 2004; Martel et al. 2013).

\section{Melt $\mathrm{SiO}_{2}$ contents}

The reported $\mathrm{SiO}_{2}$ contents of experimental glasses of the selected studies vary between $\sim 52$ and 75 wt $\%$, while the calculated melt $\mathrm{SiO}_{2}$ range from $\sim 56$ to $76 \mathrm{wt} \%$ (Fig. 3f; Table 2). Reported glass and calculated melt $\mathrm{SiO}_{2}$ contents are well-correlated overall, but the difference between reported and 
calculated values is commonly $\pm 4 \mathrm{wt} \% \mathrm{SiO}_{2}$. In our limited dataset, amphibole crystallized from intermediate and mafic starting materials also tends to calculate melt $\mathrm{SiO}_{2}$ contents that are up to $\sim 5$ $6 \mathrm{wt} \%$ lower than those of the experimental glasses (Barclay and Carmichael 2004; Pichavant et al. 2002; Sisson and Grove 1992).

\section{Discussion: Validity of the calculated parameters}

Amphibole compositions of the selected experimental studies are approximately stochiometric and all except one amphibole composition classify as "consistent" according to Ridolfi et al. (2010) (Electronic Appendix). Most amphibole also plots within the compositional fields recommended by Ridolfi and Renzulli (2012). All other amphibole plots near the recommended fields and also yields crystallization conditions comparable to the whole dataset (Fig. 2; Table 2). We therefore conclude that the selected experimental amphibole compositions should be appropriate for calculating thermobarometric and chemometric parameters using the R2010 and RR2012 calibrations.

In the following sections we evaluate the potential and problems of the new calibrations and the use of amphibole composition as a magmatic thermobarometer and chemometer. Here, we first discuss potential effects of (i) our selection of experimental amphibole and (ii) our approach to calculating pressure using equations $1 \mathrm{~b}$ and 1c. As noted in our section on "Samples and Methods", six experimental amphibole compositions exceed the maximum $\mathrm{SiO}_{2}(2.6 \%)$ or $\mathrm{Al}_{2} \mathrm{O}_{3}(7.5 \%)$ standard deviations considered by RR2012 (amphibole from samples 50-10, 50-26 of Bogaerts et al. 2006; 94 of Costa et al. (2004); 800/1/2 of Pietranik et al. 2009; B53 of Sato et al. 2005; and 87S35a\#11 of Sisson and Grove 1992; Table 2). While it is important to consider high-quality data, we find that the maximum standard deviations of $\mathrm{SiO}_{2}$ or $\mathrm{Al}_{2} \mathrm{O}_{3}$ of the six amphibole compositions have not compromised our results. Not one of them yields the largest overestimate or underestimate 
in calculated pressure relative to experimental pressure values of the individual studies or the whole dataset (Table 2).

As we have also acknowledged earlier, our approach to calculate pressure differs from the RR2012 recommended procedure, which has improved and decreased individual estimates (all values are reported in the Electronic Appendix). Altogether, the recommended procedure yields values between $\sim 150$ and $1600 \mathrm{MPa}$, while our approach yields pressure estimates between $\sim 160$ and $\sim 560 \mathrm{MPa}$ that more closely approach the experimental values of $\sim 200$ and $400 \mathrm{MPa}$. The effect of calculated pressure on calculated crystallization temperature, melt $\mathrm{H}_{2} \mathrm{O}$, and melt $\mathrm{SiO}_{2}$ is limited. However, on average our approach also yields results that approach the experimental conditions more closely than the recommended calculation procedure. Our choice of experimental amphibole compositions and calculation procedure are therefore not responsible for the problems in calculating appropriate crystallization conditions using the R2010 and RR2012 calibrations.

\section{Calculated temperature}

The overall good correlation between experimental and calculated temperatures suggests that both the R2010 and the RR2012 calibrations generally yield reasonably reliable temperature estimates. This agrees with previous studies that have demonstrated the strong temperature dependence of amphibole composition (e.g., Blundy and Cashman 2008; Holland and Blundy 1990; Shane and Smith 2013). For some amphibole compositions, the R2010 calibration yields values closer to the experimental temperatures; for others, the RR2012 calibration gives better results. It is important to note that the experimental and calculated temperatures nevertheless commonly deviate by up to $\geq 50$ ${ }^{\circ} \mathrm{C}$, which is larger than the estimated standard error, but mostly within the maximum errors of \pm 57 and $\pm 50{ }^{\circ} \mathrm{C}$ reported by R2010 and RR2012. Moreover, calculated temperatures for amphibole from alkaline magma series should be interpreted with caution, because amphibole from low-SiO${ }_{2}$ and 
high- $\mathrm{Al}_{2} \mathrm{O}_{3}$ systems significantly overestimates temperature with both calibrations (Table 2). Amphibole that crystallized from $\mathrm{H}_{2} \mathrm{O}$-rich magmas will also have a relatively $\mathrm{Al}_{2} \mathrm{O}_{3}$-rich composition and, therefore, indicate higher crystallization temperatures than amphibole crystallized from $\mathrm{H}_{2} \mathrm{O}$-poor magmas. This reflects comparatively low melt $\mathrm{SiO}_{2}$ contents resulting from suppressed plagioclase crystallization. Fractional crystallization will also affect the range of calculated amphibole crystallization temperatures, as it drives melt composition to more extreme compositions than equilibrium crystallization.

\section{Calculated pressure}

The extreme range of calculated relative to experimental pressure (Fig. 3b) shows that amphibole and the current R2010 and RR2012 calibrations cannot be used to infer crystallization pressure. The reason for the large errors in calculated pressure is that amphibole $\mathrm{Si}$ - $\mathrm{Al}$ composition is strongly correlated with amphibole/starting material composition and crystallization temperature and not with crystallization pressure (Fig. 4 versus Fig. 5). The extent of the problem has been vigorously debated for earlier amphibole barometers, even though they considered large uncertainties and were calibrated for amphibole that crystallized over comparatively small compositional and temperature intervals (e.g., Anderson and Smith 1995; Bachmann and Dungan 2002; Hammarstrom and Zen 1986, 1992; Holland and Blundy 1990; Hollister et al. 1987; Rutherford and Johnson 1989, 1992). Ridolfi et al. (2010) also describe the strong effect of temperature on amphibole composition (e.g., Fig. 5a of R2010), but the R2010 and RR2012 barometric calibrations do not adequately account for the effect. Amphibole that crystallized from mafic and felsic magmas at high and low temperature, respectively, has low and high $\mathrm{SiO}_{2} / \mathrm{Al}_{2} \mathrm{O}_{3}$ contents and therefore yields high and low pressure estimates (e.g., Fig. 5c,d). The R2010 and RR2012 databases do not capture this relationship as they are biased towards (i) amphibole crystallized from felsic to intermediate starting materials in low- 
pressure experiments $(\leq 300 \mathrm{MPa}$; exceptions are the studies of Alonso-Perez et al. 2009 and Prouteau and Scaillet 2003 used by R2010); and (ii) amphibole crystallized from intermediate to mafic starting materials in intermediate- to high-pressure experiments ( $\geq 395 \mathrm{MPa}$ and commonly >>700 MPa). Close agreement of calculated and experimental pressure values for amphibole with high $\mathrm{SiO}_{2}$ contents crystallized in low-pressure experiments (e.g. in studies of Costa et al. 2004 or Sato et al. 2005) or for amphibole with intermediate $\mathrm{SiO}_{2}$ contents crystallized in intermediatepressure experiments (e.g., study of Pichavant et al. 2002) reflect the bias of the thermobarometric database and not the applicability of the calibrations. Different calculation schemes and the R2010 versus RR2012 calibrations yield different absolute pressure values, but they all incorrectly assign increasing crystallization pressure to increasing amphibole $\mathrm{Al}_{2} \mathrm{O}_{3}$ content. To assess whether meaningful pressure estimates can be obtained with new calibrations, it is necessary to account for the effect of all crystallization conditions on amphibole composition and most importantly the effects of magma/melt composition and crystallization temperature.

\section{Calculated oxygen fugacity}

The observed scatter in estimated experimental and calculated $f \mathrm{O}_{2}$ values may reflect uncertainties of the R2010 and RR2012 calibrations as well as uncertainties of the estimated experimental values. Estimated experimental $\mathrm{fO}_{2}$ conditions are commonly inferred to be about $\pm 0.2-0.3 \log$ units (e.g., Pichavant et al. 2002; Scaillet et al. 1999). The reasonable correlation between the estimated experimental $f \mathrm{O}_{2}$ and calculated $f \mathrm{O}_{2}$ values using the $\mathrm{R} 2010$ calibration though suggests that (i) the $f \mathrm{O}_{2}$ estimates of the published studies are valid; and (ii) that the $\mathrm{R} 2010$ calibration yields reasonable estimates, at least for the range of $\mathrm{fO}_{2}$ conditions considered. The increase in calculated crystallization $f \mathrm{O}_{2}$ with increasing amphibole $\mathrm{X}_{\mathrm{Mg}}$ and decreasing $\mathrm{TiO}_{2}$ is also consistent with the experimental results (Pichavant et al. 2002; Ridolfi et al. 2008; Scaillet et al. 1999). Nevertheless, amphibole $\mathrm{SiO}_{2}$ content affects $f \mathrm{O}_{2}$ calculated with the $\mathrm{R} 2010$ calibration, yielding high $f \mathrm{O}_{2}$ values 
for evolved and low $f \mathrm{O}_{2}$ values for mafic compositions. Apparent overestimates of $f \mathrm{O}_{2}$ from amphibole composition relative to Fe-Ti oxides as reported by Bachmann et al. (2011) and Shane and Smith (2013) are, thus, expected for amphibole crystallized from evolved melts. In contrast, the large range of $\mathrm{fO}_{2}$ values determined using the RR2012 calibration and their strong positive correlation with amphibole $\mathrm{X}_{\mathrm{Mg}}$ and $\mathrm{TiO}_{2}$ and strong negative correlation with amphibole $\mathrm{SiO}_{2}$ suggests that the calculated estimates are untenable.

\section{Calculated melt $\mathrm{H}_{2} \mathrm{O}$ content}

The scatter between experimental glass $\mathrm{H}_{2} \mathrm{O}$ contents estimated by-difference and calculated melt $\mathrm{H}_{2} \mathrm{O}$ contents may reflect uncertainties of the estimated glass composition and/or problems with the employed calibrations. Uncertainties in estimated glass $\mathrm{H}_{2} \mathrm{O}$ content using the by-difference method are inferred to be $\pm 0.5 \mathrm{wt} \%$ for ideal sample and analytical conditions (Devine et al. 1995). Errors may be higher when volatile species other than $\mathrm{H}_{2} \mathrm{O}$ are present in significant abundance (e.g., $\mathrm{S}, \mathrm{Cl}$ ), or if $\mathrm{H}_{2} \mathrm{O}$-rich glasses are analyzed. However, calculated melt $\mathrm{H}_{2} \mathrm{O}$ contents and glass $\mathrm{H}_{2} \mathrm{O}$ contents estimated by more sophisticated methods (Table 2; Fig. 3e) are equally scattered. It is important to note that the estimated experimental glass $\mathrm{H}_{2} \mathrm{O}$ contents increase with amphibole $\mathrm{SiO}_{2}$ and decrease with its $\mathrm{Al}_{2} \mathrm{O}_{3}$ content. This reflects increasing melt $\mathrm{H}_{2} \mathrm{O}$ contents in equilibrium with amphibole that crystallized at decreasing temperature and from increasingly evolved melts. In contrast, calculated melt $\mathrm{H}_{2} \mathrm{O}$ contents tend to decrease with increasing amphibole $\mathrm{SiO}_{2}$ and increase with its $\mathrm{Al}_{2} \mathrm{O}_{3}$ content (Table 2; Electronic Appendix). This would indicate increasing $\mathrm{H}_{2} \mathrm{O}$ solubilities from lowtemperature felsic to high-temperature mafic melts, which is contrary to known melt $\mathrm{H}_{2} \mathrm{O}$ solubilities (e.g., summaries by Baker and Alletti 2013; Behrens and Gaillard 2003). Low calculated melt $\mathrm{H}_{2} \mathrm{O}$ contents using amphibole composition therefore reflect relatively felsic amphibole/melt/magma compositions and low crystallization temperatures, and high calculated melt $\mathrm{H}_{2} \mathrm{O}$ contents relatively 
mafic amphibole/melt/magma compositions and high crystallization temperatures. We therefore conclude that the current R2010 and RR2012 calibrations do not reliably calculate melt $\mathrm{H}_{2} \mathrm{O}$ content.

\section{Calculated melt $\mathrm{SiO}_{2}$ content}

The overall good correlation between experimental glass and calculated melt $\mathrm{SiO}_{2}$ content suggests that the R2010 yields reasonable estimates. Nevertheless, experimental and calculated $\mathrm{SiO}_{2}$ values commonly differ by up to $\pm 4 \mathrm{wt} \%$. Amphibole crystallized from mafic to intermediate starting materials appears to underestimate melt $\mathrm{SiO}_{2}$ content by up to 5-6 wt\%, but we regard this interpretation as preliminary since our dataset for these compositions is limited.

\section{Summary}

For estimating crystallization conditions using amphibole composition and the R2010 and RR2012 calibrations, we conclude that:

(i) Temperature estimates appear reasonable, although variable melt $\mathrm{H}_{2} \mathrm{O}$ contents and fractional versus equilibrium crystallization affect the range of the estimates.

(ii)Pressure estimates are untenable, where high and low calculated pressures reflect crystallization from mafic high-temperature and felsic low-temperature magmas.

(iii) Calculated $f \mathrm{O}_{2}$ appears reasonable for moderately reduced and oxidized conditions using the R2010 calibration, although estimates are affected by amphibole $\mathrm{SiO}_{2}$ composition. The RR2012 calibration yields untenable estimates.

(iv) Calculated melt $\mathrm{H}_{2} \mathrm{O}$ contents are incorrect estimates, increasing from felsic to mafic magmas and for amphibole crystallized at low to high temperature. 
(v)Calculated melt $\mathrm{SiO}_{2}$ contents using the RR2012 calibration appear reasonable, but possibly underestimate melt $\mathrm{SiO}_{2}$ contents for mafic and intermediate amphibole/magma compositions.

We consider it essential that future studies determine for which range in conditions amphibole thermobarometres and chemometers can be used, and that they rigorously correct for the effects of all crystallization parameters on amphibole composition, as concluded in earlier studies (e.g., Anderson and Smith 1995; Holland and Blundy 1990; De Angelis et al. 2013). It is also essential that users have tight constraints on magmatic components and processes and some independent quantitative constraints on crystallization conditions.

\section{AMPHIBOLE IN MERAPI PYROCLASTS}

Amphibole from Merapi pyroclasts has previously been used to calculate pressure and temperature crystallization conditions, which in turn have been used to estimate pre-eruptive magma storage conditions (Costa et al. 2013; Nadeau et al. 2013; Peters et al. 2011). Below, we present new textural and compositional data for amphibole phenocrysts and megacrysts, which we later interpret using the findings summarized above.

\section{Results: Amphibole crystal populations}

Our juvenile samples of the 2010 eruption are crystal-rich with $\leq 40$ vol\% macro- and microphenocrysts (vol\% were point-counted and calculated on a vesicle-free basis). They are dominated by plagioclase ( $\leq 30 \mathrm{vol} \%)$ and clinopyroxene ( $\leq 10 \mathrm{vol} \%)$, contain lesser amounts of amphibole ( 1-3 vol\%), orthopyroxene ( 1-2 vol\%), and magnetite ( 2-4 vol\%), and have traces of olivine. Amphibole forms four texturally and compositionally distinct crystal populations (Fig. 6; 
Table 3): (i) Small, normally-zoned phenocrysts (Type-P1); (ii) large, reversely-zoned phenocrysts (Type-P2); (iii) euhedral to subhedral, low $\mathrm{SiO}_{2}$ megacrysts (Type-M1); and (iv) subhedral to anhedral, high $\mathrm{SiO}_{2}$ megacrysts (Type-M2). Their textural and compositional characteristics and calculated crystallization conditions are detailed below.

\section{Amphibole phenocrysts}

The Type-P1 and Type-P2 phenocrysts are present in all our juvenile samples with $<5$ to $\sim 80$ crystals per thin section. The Type-P1 phenocrysts are commonly $<500 \mu \mathrm{m}$ long, typically form single crystals or small crystal clusters (Fig. 6a; Table 3). Some crystals are fragmented, while most display limited resorption and rounding. In dome samples, phenocrysts commonly have no and rarely have $<3 \mu \mathrm{m}$ wide aureoles of acicular pyroxene \pm plagioclase \pm oxide and glass (Fig. 7a). Amphibole phenocrysts in pumice samples have aureoles of acicular pyroxene \pm plagioclase \pm oxide and glass that are on average up to $\sim 10 \mu \mathrm{m}$ wide (Fig. $7 \mathrm{~b}$ ). The Type-P1 phenocrysts have predominantly magnesiohastingsite composition, but few classify as tschermakitic pargasite, showing a large compositional range with $\sim 39-43 \mathrm{wt} \% \mathrm{SiO}_{2}, \sim 1.9-3.5 \mathrm{wt} \% \mathrm{TiO}_{2}, \sim 10.3-14.3 \mathrm{wt} \% \mathrm{Al}_{2} \mathrm{O}_{3}, \sim 11.8-16.0$ wt $\% \mathrm{FeO}, \sim 11.3-14.2$ wt\% $\mathrm{MgO}$, and $~ 10.8-12.1$ wt\% $\mathrm{CaO}$ (Fig. 8; Table 4). Their compositional range translates into calculated crystallization conditions between (a) $\sim 1020{ }^{\circ} \mathrm{C}, \sim 650 \mathrm{MPa}$, an $f \mathrm{O}_{2}$ of $\sim \mathrm{NNO}+0.5$, and melt $\mathrm{H}_{2} \mathrm{O}$ and $\mathrm{SiO}_{2}$ contents of $\sim 6.5$ and $60 \mathrm{wt} \%$; and (b) $\sim 925{ }^{\circ} \mathrm{C}, \sim 270 \mathrm{MPa}$, an $f \mathrm{O}_{2}$ of $\sim \mathrm{NNO}+1$, and melt $\mathrm{H}_{2} \mathrm{O}$ and $\mathrm{SiO}_{2}$ contents of $\sim 4.5$ and 67 wt\% (all values except melt $\mathrm{SiO}_{2}$ were calculated using the R2010 calibration; Fig. 9; Table 4). Core-rim zoning of Type-P1 phenocrysts is normal towards high-SiO 2 rims that give low calculated pressure, temperature and melt $\mathrm{H}_{2} \mathrm{O}$ contents, and increasing $f \mathrm{O}_{2}$ values (Fig. 10).

The Type-P2 phenocrysts form crystals that are up to $\sim 3 \mathrm{~mm}$ long and thus larger than the Type-P1 phenocrysts (Table 3; Fig. 6b versus Fig. 6a). They typically form single crystals or small 
crystal clusters, may be fragmented and are commonly partially resorbed, similar to the Type-P1 phenocrysts. They also have no or very thin reaction rims in dome pyroclasts and, on average, up to $\sim 10 \mu \mathrm{m}$ wide reaction rims in pumice samples. Their composition ranges from magnesiohastingsite to tschermakitic pargasite. Compared to the Type-P1 phenocrysts, they tend to high $\mathrm{SiO}_{2}(\sim 40-44$ wt $\%)$ and $\mathrm{MgO}(\sim 12.4-14.4 \mathrm{wt} \%)$ and low $\mathrm{Al}_{2} \mathrm{O}_{3}(\sim 10.0-12.0 \mathrm{wt} \%)$ and $\mathrm{CaO}(\sim 10.4-11.6 \mathrm{wt} \%)$ contents (Fig. 8). Calculated crystallization conditions range between $\sim 900-950{ }^{\circ} \mathrm{C}, 230-390 \mathrm{MPa}$, an $f \mathrm{O}_{2}$ of $\sim \mathrm{NNO}+0.5$ to $\mathrm{NNO}+1.0$, and melt $\mathrm{H}_{2} \mathrm{O}$ and $\mathrm{SiO}_{2}$ contents of $\sim 3.6-5.1 \mathrm{wt} \%$ and $\sim 63-71$ wt $\%$ (all values, except melt $\mathrm{SiO}_{2}$, were calculated using the R2010 calibration; Fig. 9; Table 4). The crystals exhibit weak oscillatory and reverse zoning with a rim-ward decrease in $\mathrm{SiO}_{2}$ that translates into an increase in calculated pressure, temperature and melt $\mathrm{H}_{2} \mathrm{O}$, and decreasing $f \mathrm{O}_{2}$ (Fig. 10).

\section{Amphibole megacrysts}

The abundance of amphibole megacrysts is typically $\leq 1$ vol\%, where one or both megacryst types may occur in single samples. The Type-M1 megacrysts are present in some samples, while the TypeM2 megacrysts are present in most samples. The Type-M1 crystals are up to $\sim 2 \mathrm{~cm}$ long and predominantly form single crystals or cluster with clinopyroxene (Fig. 6c). Most crystals show healed or resorbed micro fractures and some display patchy optical zoning. All crystals have reaction rims typically $\sim 300-500 \mu \mathrm{m}$ wide that are composed of subhedral plagioclase, clinopyroxene, oxide, and orthopyroxene. The Type-M1 megacrysts classify as magnesiohastingsite, have low $\mathrm{SiO}_{2}, \mathrm{TiO}_{2}$, and $\mathrm{FeO}$ contents $\left(\sim 39-40,1.8-2.1\right.$, and 11.7-13.1 wt\%) and high $\mathrm{Al}_{2} \mathrm{O}_{3}$ and $\mathrm{CaO}$ contents $(\sim 14.4-$ 14.9 and 11.7-12.3 wt\%), and are normally zoned (Fig. 8; Table 4). It is notable that they have higher $\mathrm{K}_{2} \mathrm{O}$ contents than all other amphibole types analyzed (Fig. 8h). Calculated crystallization conditions are $\sim 1025-1040{ }^{\circ} \mathrm{C}, \sim 700-760 \mathrm{MPa}$, an $f \mathrm{O}_{2}$ of $\sim \mathrm{NNO}+0.4$ to $\mathrm{NNO}+0.7$, and melt $\mathrm{H}_{2} \mathrm{O}$ and $\mathrm{SiO}_{2}$ 
contents of $\sim 6-7 \mathrm{wt} \%$ and $\sim 59-61 \mathrm{wt} \%$ (all values except melt $\mathrm{SiO}_{2}$ were calculated using the R2010 calibration; Fig. 9).

The Type-M2 megacrysts are commonly $<1 \mathrm{~cm}$ long and, thus, smaller than the Type-M1 megacrysts, and predominantly occur in clusters with resorbed plagioclase, clinopyroxene, and oxides (Fig. 6d). Their reaction rims are $>300 \mu \mathrm{m}$ and up to $\sim 1500 \mu \mathrm{m}$ wide, are finer-gained than the Type-M1 rims, but also consist of subhedral plagioclase, clinopyroxene, oxide, and orthopyroxene (Fig. 7c). The Type-M2 megacrysts classify as magnesiohastingsite and tschermakitic pargasite. They have high $\mathrm{SiO}_{2}, \mathrm{TiO}_{2}$, and $\mathrm{FeO}$ contents ( 41-43, 2.0-3.3, and 12.0-14.7 wt\%) and low $\mathrm{Al}_{2} \mathrm{O}_{3}$ and $\mathrm{CaO}$ contents ( 10.9-12.3 and 10.6-11.5 wt $\left.\%\right)$ compared to the Type-M1 megacrysts, but compositionally overlap with $\mathrm{SiO}_{2}$-rich phenocrysts (Fig. 8; Table 4). Crystals are normally to reversely, or largely unzoned. Their calculated crystallization conditions are $\sim 965-920{ }^{\circ} \mathrm{C}, \sim 390-290$ $\mathrm{MPa}$, and an $f \mathrm{O}_{2}$ of $\sim \mathrm{NNO}+0.4$ to $\mathrm{NNO}+0.8$ (Fig. 9a,b). Calculated host melt $\mathrm{H}_{2} \mathrm{O}$ and $\mathrm{SiO}_{2}$ compositions are estimated to range between $\sim 4-6 \mathrm{wt} \%$ and $\sim 63-71 \mathrm{wt} \%$ (all values except $\mathrm{melt}^{\mathrm{SiO}_{2}}$ were calculated using the R2010 calibration; Fig. 9c,d).

\section{Discussion: Amphibole in Merapi’s magma system}

In the following sections we evaluate amphibole's record of crystallization conditions and processes in Merapi's plumbing system. We first discuss the origin of amphibole megacrysts and phenocrysts and then proceed to a discussion of the crystallization conditions calculated from their compositions. As concluded in the first part of this paper, we consider (i) calculated crystallization temperatures as reasonable estimates; (ii) calculated $f \mathrm{O}_{2}$ and melt $\mathrm{SiO}_{2}$ content as uncertain, yet potentially useful estimates; and (iii) calculated crystallization pressure and melt $\mathrm{H}_{2} \mathrm{O}$ as untenable estimates. 


\section{Amphibole origins}

Amphibole phenocrysts in Merapi's eruptive products have been previously considered to be of cognate magmatic origin (e.g., Chadwick et al. 2013; Nadeau et al. 2013; Preece et al. 2013). Their euhedral to subhedral shape in the 2010 samples and their $<10 \mu \mathrm{m}$ wide, glass-bearing reaction rims are in agreement with this interpretation. We further suggest that the normal zoning of Type-P1 crystals signifies a cognate magmatic origin, recording crystallization from an evolving recharge magma (Table 3). However, the relatively large size yet evolved composition and reverse zoning of Type-P2 phenocrysts is inconsistent with a cognate origin, but compatible with an antecrystic origin (Table 3). Accordingly, we interpret the high-SiO 2 cores of the Type-P2 phenocrysts to record crystallization from an evolved resident magma, and the low-SiO 2 rims to record growth following mafic recharge. Bachmann and Dungan (2002) have previously interpreted reversely-zoned amphibole from Fish Canyon magmas to have formed as a result of reheating and mafic recharge of an evolved, rhyolitic reservoir. For Merapi's magmas, the reverse zoning of amphibole was previously inferred to reflect crystallization kinetics, while mafic recharge has been inferred on the basis of plagioclase and clinopyroxene zoning (Costa et al. 2013).

Amphibole megacrysts in Merapi's eruptive products have been interpreted as xenocrysts and/or antecrysts (e.g., Chadwick et al. 2013; Nadeau et al. 2013; Peters et al. 2011). Our findings agree with this interpretation. We propose that the Type-M1 megacrysts are xenocrysts derived from mafic cumulates, which is consistent with their large size, common micro fractures, high calculated crystallization temperatures, and calculated host melt $\mathrm{SiO}_{2}$ compositions of $\leq 60 \mathrm{wt} \%$ (Table 3 and 4). The patchy compositional zoning of Type-M1 megacrysts may reflect partial dissolutionrecrystallization during cumulate remobilization or diffusive re-equilibration during magma residence (Hammarstrom and Zen 1992; Thornber et al. 2008). Coarse-grained, glass-free reaction rims may signify reaction driven by decompresssion and/or disequilibrium with their host melt 
(Rutherford and Devine 2008). For the subhedral-anhedral Type-M2 megacrysts we infer that they are xenocrysts and/or antecrysts derived from evolved crystal mush or fully crystallized magma pockets (Table 3), evidenced by their evolved compositions, low calculated crystallization temperatures, and common presence in plagioclase, clinopyroxene, and oxide clusters. Their wide, coarse-grained and glass-free reaction rims may signify resorption driven by heating and/or compositional disequilibrium with their host melt (Rutherford and Devine 2008).

\section{Calculated crystallization conditions}

As concluded above, we consider pressure values calculated using amphibole composition as an artefact of amphibole crystallization from compositionally variable magmas and, as such, untenable. We therefore caution that lower and mid- to upper crustal magma reservoirs inferred below Merapi and other arc volcanoes using amphibole composition (Fig. 1) are unsubstantiated. For Merapi's plumbing system, we propose that the inferred reservoirs at (i) $\sim 650-800 \mathrm{MPa}(\sim 22-28 \mathrm{~km}$ deep) and $\sim 450-250 \mathrm{MPa}(\sim 15-8 \mathrm{~km}$ deep) (Costa et al. 2013; Nadeau et al. 2013); and (ii) our calculated pressure values between $\sim 250$ and $650 \mathrm{MPa}$ for phenocrysts and Type-M2 megacrysts record crystallization from mafic to evolved magmas. Whether these magmas partially crystallized at significantly different depths needs to be experimentally constrained.

Amphibole crystallization in basaltic andesitic to intermediate magmas typically takes place at temperatures of $\leq 1000{ }^{\circ} \mathrm{C}$ (e.g., Bogaerts et al. 2006; Pichavant et al. 2002). The high crystallization temperatures of $\sim 1030-1050{ }^{\circ} \mathrm{C}$ calculated for the Type-M1 megacrysts and mafic Type-P1 phenocrysts point to a large amphibole stability field and crystallization from basaltic magmas, and/or they reflect failings in the estimates or the actual value uncertainties of $\pm 22{ }^{\circ} \mathrm{C}$. The lower calculated crystallization temperatures of predominantly $920-970{ }^{\circ} \mathrm{C}$ calculated for Type-P1 and Type-P2 phenocrysts are consistent with crystallization from evolved magmas. 
The calculated $f \mathrm{O}_{2}$ conditions between $\sim \mathrm{NNO}+0.5$ and $\sim \mathrm{NNO}+1$ are typical for mafic to intermediate arc magmas (Behrens \& Gaillard 2003). The relatively oxidized conditions calculated for Type-P2 phenocrysts and Type-M2 megacrysts are consistent with upper crustal crystallization of an evolved residence magma, while the more reduced conditions calculated for the $\mathrm{SiO}_{2}$-poor TypeP1 crystals concur with crystallization from mafic recharge magma. While the estimates appear reasonable, we caution that they may be overestimates for evolved amphibole compositions and underestimates for mafic amphibole compositions. They should thus be considered as preliminary until further evaluation.

The calculated melt $\mathrm{SiO}_{2}$ contents of $\sim 60$ to $71 \mathrm{wt} \%$ in equilibrium with Type-P1 and TypeP2 phenocrysts are close to the previously reported $\sim 62-71 \mathrm{wt} \% \mathrm{SiO}_{2}$ for glasses of the juvenile 2010 pyroclasts (Borisova et al. 2013; Costa et al. 2013; all values normalized to 100\% anhydrous). We, therefore, consider the calculated melt $\mathrm{SiO}_{2}$ contents as reasonable approximates. We infer that they record the crystallization of antecrystic Type-P2 amphibole in an evolved resident reservoir in equilibrium with intermediate to evolved dacitic melts. The Type-M2 megacrysts with equivalent compositions are interpreted as xenocrysts and/or antecrysts derived from similarly evolved, fully, or partially crystallized reservoirs. The large range in melt $\mathrm{SiO}_{2}$ contents inferred from cognate Type-P1 phenocrysts is consistent with crystallization from andesitic to dacitic melts during fractionation and mixing of a more mafic recharge magma with a relatively evolved residence magma. The calculated andesitic melt in equilibrium with Type-M1 megacrysts reveals early, high-temperature amphibole fractionation and points to the formation of amphibole-bearing cumulates. The ubiquitous presence of Type-M1 xenocrysts in Merapi's pyroclasts indicates that amphibole-bearing mafic cumulates play an important role in Merapi's plumbing system, as previously suggested by Chadwick et al. (2013).

The calculated melt $\mathrm{H}_{2} \mathrm{O}$ contents of $\sim 3.5-7$ wt $\%$ overlap with, but are higher than values of $<5-6 \mathrm{wt} \%$ and commonly $<2 \mathrm{wt} \% \mathrm{H}_{2} \mathrm{O}$ determined for inclusions and matrix glasses of the 2010 
pyroclasts (Borisova et al. 2013; Costa et al. 2013). The calculated values seem to be plausible estimates, but we caution that they largely reflect variations in crystallization temperature and magma composition that overestimate $\mathrm{H}_{2} \mathrm{O}$ contents for high-temperature mafic melts and underestimate $\mathrm{H}_{2} \mathrm{O}$ contents for low-temperature felsic melts.

Summary

As summarized in Figure 11, we suggest for amphibole crystals from Merapi's 2010 pyroclasts that:

(i) Textures and compositions reveal the presence of cognate and antecrystic phenocrysts as well as megacrystic, cumulate- and magma mush-derived xenocrysts (Fig. 11 a-c).

(ii) Cognate phenocrysts crystallized from a mafic recharge magma in equilibrium with andesitic to dacitic host melts (Fig. 11 a,d,e); antecryst formed in equilibrium with a dacitic melt (Fig. $11 \mathrm{~b}, \mathrm{~d}, \mathrm{f})$.

(iii) Crystallization temperatures of cognate phenocrysts and antecrysts were $\geq 980{ }^{\circ} \mathrm{C}$ and $\geq 920$ ${ }^{\circ} \mathrm{C}$, while $f \mathrm{O}_{2}$ presumably ranged between $\geq \mathrm{NNO}+0.4$ and $\leq \mathrm{NNO}+1$ (Fig. 10d).

(iv) Calculated crystallization pressures and melt $\mathrm{H}_{2} \mathrm{O}$ contents are untenable, where variations reflect amphibole crystallization during magma mixing and fractionation.

(v) Amphibole phenocrysts record that pyroclasts erupted in 2010 represent well-mixed recharge and resident magmas (Fig. $11 \mathrm{c}, \mathrm{g}, \mathrm{h})$.

\section{CONCLUSIONS}

Interpreting amphibole composition for constraining pre-eruptive crystallization conditions should be done with caution. A prerequisite is the careful study of textures and zoning patterns of the amphibole crystals to determine amphibole origins, and processes and components of open- and closed-system crystallization. Amphibole relatively reliably records magmatic temperatures because 
its composition is strongly controlled by magma and melt composition and crystallization temperature. However, large apparent pressure variations as those calculated for amphibole from many arc volcanoes (e.g., Mount Saint Helens, El Reventador, Fig. 1; our Merapi 2010 data, Fig. 9a) reveal thorough mixing of mafic to felsic magmas and temperature variations rather than crystallization over a large depth range. High- and low-pressure estimates (e.g, for Soufrière Hills, Redoubt; Fig. 1) are consistent with amphibole crystallization from mafic and more evolved magmas, respectively, and should not necessarily be taken as evidence for lower and upper crustal magma storage and crystallization. To calculate meaningful crystallization pressure and melt $\mathrm{H}_{2} \mathrm{O}$ from amphibole composition (e.g., temperature-pressure or temperature-melt $\mathrm{H}_{2} \mathrm{O}$ content), future calibrations will have to rigorously correct for the effects of all other crystallization parameters on amphibole composition, and likely be combined with independent estimates of one or more of the parameters. Robust calibrations may perhaps be best developed for amphibole and host melt/magma with a limited compositional and temperature range (i.e. for specific coexisting assemblages as in early calibrations), while using the largest possible datasets for their solution.

\section{ACKNOWLEDGEMENTS}

This research was funded by the French Ministry of Scientific Researches, ANR-Blanc DOMERAPI to J.-P. Métaxian and co-workers. We thank J.-C. Komoroswki for invaluable guidance in the field and for stratigraphic explanations. C. Noer, L. Arbaret, and A. Burgisser are thanked for interesting discussions during the field mission. J.-L. Bourdier is thanked for sharing his knowledge on Merapi's eruption dynamics. I. Di Carlo provided much assistance with SEM imaging and microprobe analyses and shared many thoughts on amphibole textures and composition. Reviews by $\mathrm{O}$. Bachmann, F. Ridolfi, and P. Shane, and J. Hoefs' editorial assistance are greatly appreciated. 


\section{REFERENCES}

Anderson JL, Smith DR (1995) The effects of temperature and $f \mathrm{O}_{2}$ on the Al-in hornblende barometer. Am Mineral 80:549-559

Arculus RJ, Wills KJA (1980) The petrology of plutonic blocks and inclusions from the Lesser Antilles island arc. J Petrol 21:743-799

Bachmann O, Dungan M (2002) Temperature-induced Al-zoning in hornblendes of the Fish Canyon magma, Colorado. Am Mineral 87:1062-1076

Bachmann O, Deering CD, Ruprecht JS, Huber C, Skopelitis A, Schnyder C (2012) Evolution of silicic magmas in the Kos-Nisyros volcanic center, Greece: cycles associated with caldera collapse. Contrib Mineral Petrol 163:151-166

Baker DR, Alletti M (2012) Fluid saturation and volatile partitioning between melts and hydrous fluids in crustal magmatic systems: The contribution of experimental measurements and solubility models. Earth Sci Rev 114:298-324

Barnes CG (1987) Mineralogy of the Wooley Creek batholith, Slinkard pluton, and related dikes, Klamath mountains, Northern California. Am Mineral 72:87-901

Behrens H, Gaillard F (2006) Geochemical aspects of melts, volatiles and redox behavior. Elements 2:275-280

Barclay J, Carmichael ISE (2004) A hornblende basalt from western Mexico: Water-saturated phase relations constrain a pressure-temperature window of eruptibility. J Petrol 45:485-506

Blundy J, Cashman K (2008) Petrologic reconstruction of magmatic system variables and processes. Rev Mineral Geochem 69:179-239

Blundy JD, Holland TJB (1990) Calcic amphibole equilibria and a new amphibole-plagioclase geothermometer. Contrib Mineral Petrol 104: 208-224. 
Bogaerts M, Scaillet B, Vander Auwera J (2006) Phase equilibria of the Lyngdal granodiorite (Norway): Implications for the origin of metaluminous ferroan granitoids. J Petrol 47:24052431

Borisova AY, Martel C, Gouy S, Pratomo I, Sumarti S, Toutain J-P, Bindeman IN, de Parseval P, Metaxian J-P, Surono (2013) Highly explosive 2010 Merapi eruption: Evidence for shallowlevel crustal assimilation and hybrid fluid. J Volcanol Geotherm Res 261:193-208

Cawthorn RG, Curran EB, Arculus RJ (1973) A petrogenetic model for the origin of the calcalkaline suite of Grenada, Lesser Antilles. J Petrol 14:327- 337

Chadwick JP, Troll VR, Waight TE, van der Zwan FM, Schwarzkopf LM (2013) Petrology and geochemistry of igneous inclusions in recent Merapi deposits: a window into the deep plumbing system. Contrib Mineral Petrol 165:259-282

Costa F, Scaillet B, Pichavant M (2004) Petrological and experimental constraints on the preeruption compositions of Holocene dacite from Volcàn San Pedro $\left(36^{\circ} \mathrm{S}\right.$, Chilean Andes $)$ and importance of sulphur in silicic subduction-related magmas. J Petrol 45:855-881

Costa F, Andreastuti S, Bouvet de Maisonneuve C, Pallister JS (2013) Petrological insights into the storage conditions, and magmatic processes that yielded the centennial 2010 Merapi explosive eruption. J Volcanol Geotherm Res 261:209-235

Davidson J, Turner S, Handley H, Macpherson C, Dosseto A (2007) Amphibole "sponge" in arc crust? Geology 35:787-790

De Angelis SH, Larsen J, Coombs M (2013) Pre-eruptive magmatic conditions at Augustine Volcano, Alaska, 2006: Evidence from amphibole geochemistry and textures. J Petrol 54:1939-1961

Devine JD, Gardner JE, Brack HP, Layne GD, Rutherford MJ (1995) Comparison of microanalytical methods for estimating $\mathrm{H}_{2} \mathrm{O}$ contents of silicic volcanic glasses. Am Mineral 80:319-328 
Foley FV, Pearson NJ, Rushmer T, Turner S, Adam J (2013) Magmatic evolution and magma mixing of Quaternary adakites at Solander and Little Solander Islands, New Zealand. J Petrol $54: 703-744$

Hammarstrom JM, Zen E-A (1986) Aluminium in hornblende: an empirical igneous geobarometer. Am Mineral 71:1297-1313

Hammarstrom JM, Zen E-A (1992) Discussion of "Calcic amphibole equilibria and a new amphibole-plagioclase geothermometer". Contrib Mineral Petrol 111:264-266

Holland T, Blundy J (1994) Non-ideal interactions in calcic amphiboles and their bearing on amphibole-plagioclase thermometry. Contrib Mineral Petrol 116:433-447

Hollister LS, Grissom GC, Peters EK, Stowell HH, Sisson VB (1987) Confirmation of the empirical correlation of $\mathrm{Al}$ in hornblende with pressure of solidification of calc-alkaline plutons. Am Mineral 72:231-239

Johnson MC, Rutherford MJ (1989) Experimental calibration of the aluminum-in-hornblende geobarometer with application to Long Valley caldera (California) volcanic rocks. Geology $17: 837-841$

Leake BE, Woolley AR, Arps CES, Birch WD, Gilbert MC, Grice JD, Hawthorne FC, Kato A, Kisch HJ, Krivovichev VG, Linthout K, Laird J, Mandarino J, Maresch WV, Nickel EH, Schumaker JC, Smith DC, Stephenson NCN, Ungaretti L, Whittaker EJW, Youzhi G (1997) Nomenclature of amphiboles: report of the subcommittee on amphiboles of the International Mineralogical Association Commission on New Minerals and Mineral Names.

Martel C, Champallier R, Prouteau G, Pichavant M, Arbaret L, Balcone-Boissard H, Boudon G, Boivin P, Bourdier J-L, Scaillet B (2013) Trachyte phase relations and implication for magma storage conditions in the Chaîne des Puys (French Massif Central). J Petrol 54:1071-1107 
Nadeau O, Williams-Jones AE, Stix J (2013) Magmatic-hydrothermal evolution and devolatilization beneath Merapi volcano, Indonesia. J Volcanol Geotherm Res 261:50-68

Peters STM, Chadwick JP, Troll VR (2011) Amphibole antecrysts in deposits of Merapi volcano, Indonesia: a plutonic phase in extrusive magmas. Goldschmidt supplement. Mineral Mag $75: 1627$

Pichavant M, Martel C, Bourdier JL, Scaillet B (2002) Physical conditions, structure, and dynamics of a zoned magma chamber: Mount Peleé (Martinique, Lesser Antilles Arc). J Geophys Res 107(B5):2093. doi:10.1029/2001JB000315

Pietranik A, Holtz F, Koepke J, Puziewicz J (2009) Crystallization of quartz dioritic magmas at 2 and 1 kbar: experimental results. Mineral Petrol 97:1-21

Preece K, Barclay J, Gertisser R, Herd RA (2013) Textural and micro-petrological variations in the eruptive products of the 2006 dome-forming eruption of Merapi volcano, Indonesia: Implications for sub-surface processes. J Volcanol Geotherm Res 261:98-120

Ridolfi F, Purerini M, Renzulli A, Menna M, Toulkeridis T (2008) The magmatic feeding system of El Reventador volcano (Sub-Andean zone, Ecuador) constrained by texture, mineralogy and thermobarometry of the 2002 erupted products. J Volcanol Geotherm Res 176:94-106

Ridolfi F, Rezulli A, Puerini M (2010) Stability and chemical equilibrium of amphibole in calcalkaline magmas: an overview, new thermobarometric formulations and application to subduction-related volcanoes. Contrib Mineral Petrol 160:45-66

Ridolfi F, Renzulli A (2012) Calcic amphiboles in calc-alkaline and alkaline magmas: thermobarometric and chemometric empirical equations valid up to $1130{ }^{\circ} \mathrm{C}$ and $2.2 \mathrm{GPa}$. Contrib Mineral Petrol 163: 877-895

Rutherford MJ, Johnson MC (1992) A comment on "Calcic amphibole equilibria and a new amphibole-plagioclase geothermometer". Contributions to Mineralogy and Petrology, $111: 266-268$ 
Rutherford MJ, Devine JD (2003) Magmatic conditions and magma ascent as indicated by hornblende phase equilibria and reactions in the 1995-2002 Soufrière Hills magma. J Petrol 44:1433-1454

Rutherford MJ, Devine JD (2008) Magmatic conditions and processes in the storage zone of the 2004-2006 Mount St. Helens Dacite. In: Sherrod DR, Scott WE, Stauffer PH (eds) A Volcano Rekindled: The renewed eruption of Mount St. Helens, 2004-2006. US Geol Surv Prof Paper 1750, Chapter 31, pp 703-725

Sato H, Holtz F, Beherens H, Botcharnikov R, Nakada S (2005) Experimental petrology of the 1991-1995 Unzen Dacite, Japan. Part II: Cl/OH partitioning between hornblende and melt and its implications for the origin of oscillatory zoning of hornblende phenocrysts. J Petrol 42:339-354

Scaillet B, Evans BW (1999) The 15 June 1991 eruption of Mount Pinatubo. I. Phase equilibria and pre-eruption P-T- $f \mathrm{O}_{2}-f \mathrm{H}_{2} \mathrm{O}$ conditions of the dacite magma. J Petrol 40:381-411

Schmidt MW (1992) Amphibole composition in tonalite as a function of pressure; an experimental calibration of the Al-in-hornblende barometer. Contrib Mineral Petrol 110:304-310

Scott JAJ, Mather TA, Pyle DM, Rose WI, Chigna G (2012) The magmatic plumbing system beneath Santiaguito Volcano, Guatemala. J Volcanol Geotherm Res 237-238:54-68

Shane P, Smith VC (2013) Using amphibole crystals to reconstruct magma storage temperatures and pressures for the post-caldera collapse volcanism at Okataina volcano. Lithos 156-159:159170

Sisson TW, Grove TL (1992) Experimental investigations of the role of $\mathrm{H}_{2} \mathrm{O}$ in calc-alkaline differentiation and subduction zone magmatism. Contrib Mineral Petrol 113:143-166

Thornber CR, Pallister JS, Lowers HA, Rowe MC, Mandeville CW, Meeker GP (2008) Chemistry, mineralogy, and petrology of amphibole in Mount St. Helens 2004-2006 dacite. In: Sherrod 
DR, Scott WE, Stauffer PH (eds) A Volcano Rekindled: The renewed eruption of Mount St. Helens, 2004-2006. US Geol Surv Prof Paper 1750, pp727-754

Turner SJ, Izbekov P, Langmuir C (2013) The magma plumbing system of Bezymianny Volcano: Insights from a 54 year time series of trace element whole-rock geochemistry and amphibole compositions. . J Volcanol Geotherm Res 263:108-121 


\section{FIGURE CAPTIONS}

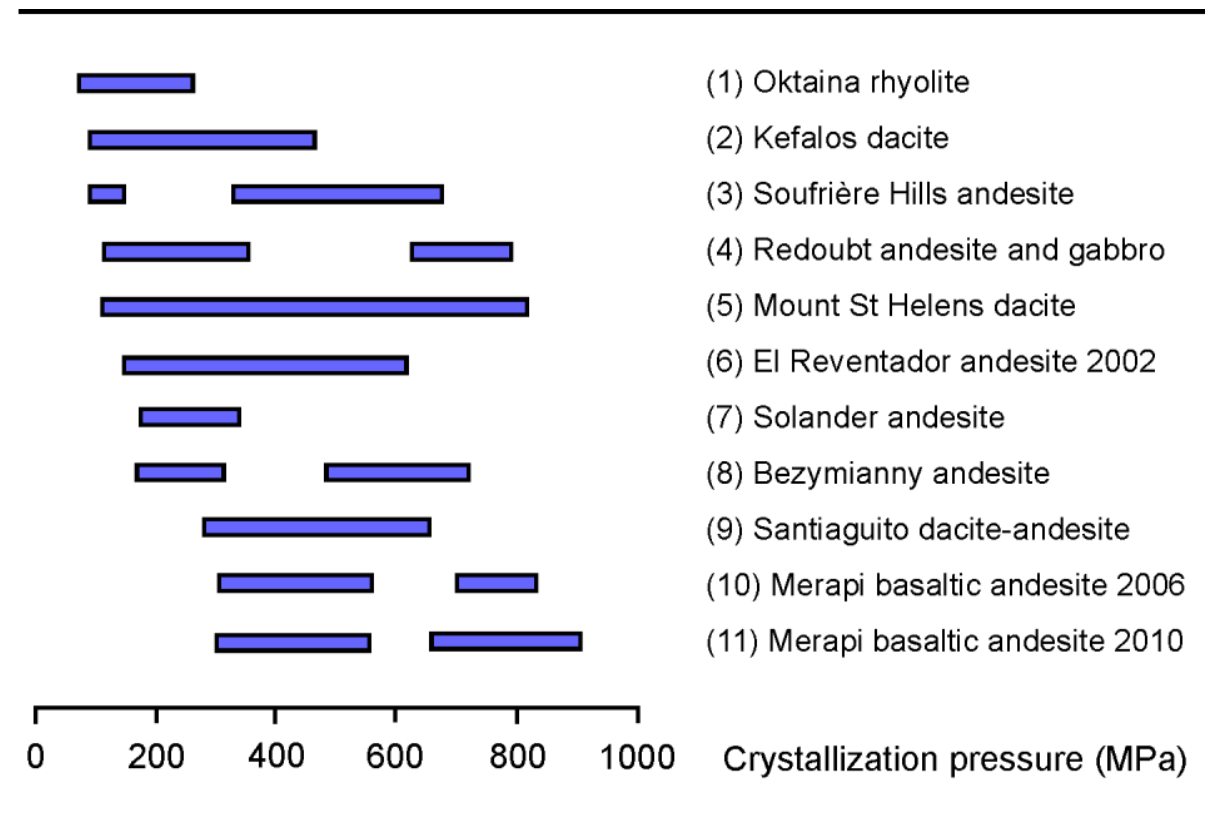

Figure 1 - Erdmann et al.

Figure 1: Calculated crystallization pressure for amphibole from rhyolitic to basaltic-andesitic magmas. Data are from: (1) Shane and Smith 2013; (2) Bachmann et al. 2011; (3-6) Ridolfi et al. (2010); (7) Foley et al. 2013; (8) Turner et al. 2013; (9) Scott et al. (2012); and (10,11) Costa et al. 2013. Costa et al. (2013) employed the RR2012 calibration; all other studies used the R2010 calibration. 

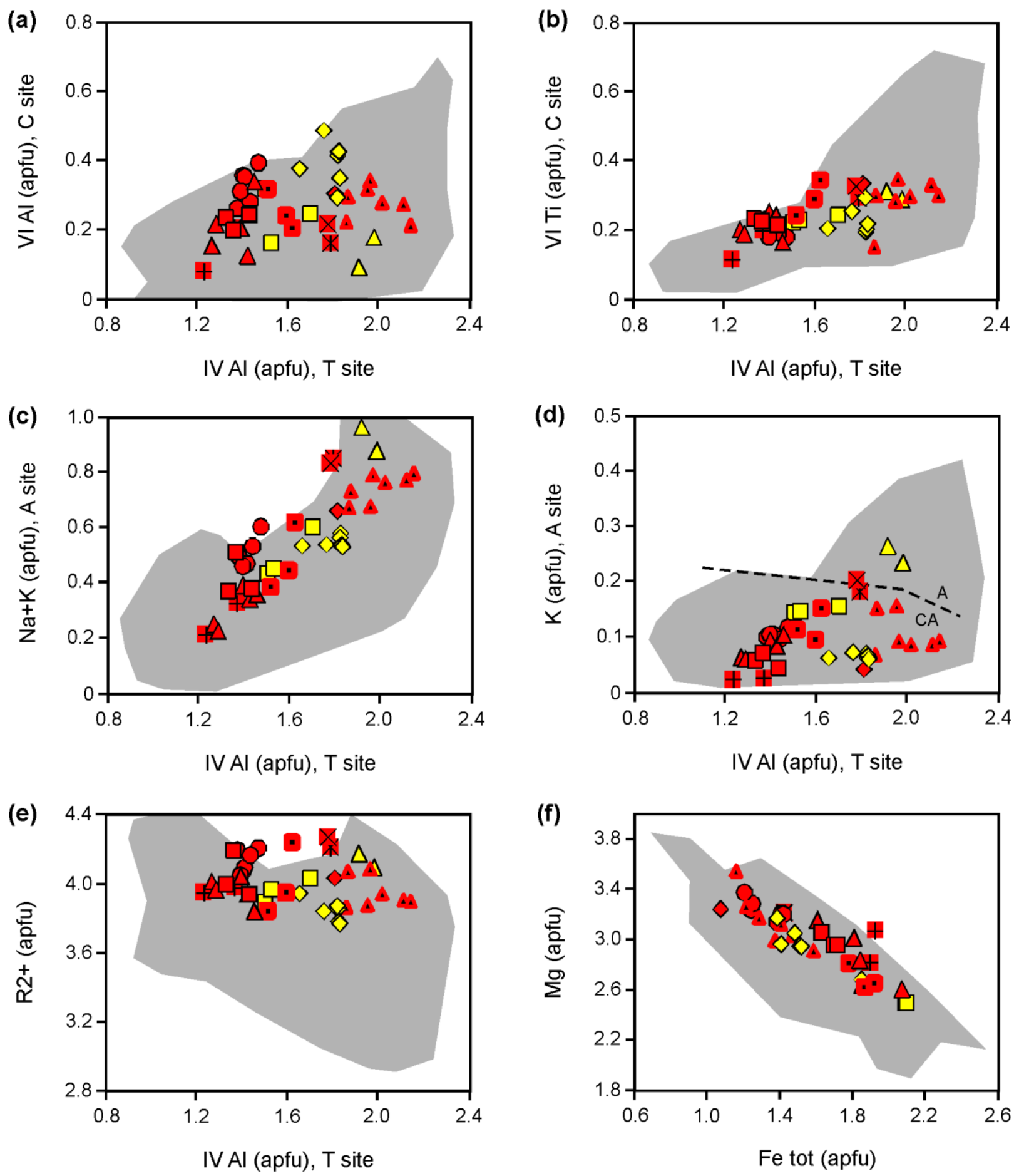

Fe tot (apfu)

Barclay \& Carmichael 2004

$\square$ Bogaerts et al. 2006

Costa et al. 2004

Grove et al. 2003
Martel et al. 2013

$\triangle$ Martel et al. 2013

$\diamond$ Pichavant et al. 2002

- Pietranik et al. 2009
Rutherford \& Devine 2003

$\triangle$ Sato et al. 2005

$\square$ Scaillet \& Evans 1999

^ Sisson \& Grove 1992

Figure 2 - Erdmann et al. 
Figure 2: Cation variation diagrams for amphibole from the selected experimental studies compared to the compositional fields recommend by RR2012. Grey fields outline the compositional range of amphibole used in the RR2012 calibration. Red symbols are for amphibole from $200 \mathrm{MPa}$ experiments; yellow symbols are for amphibole from $400 \mathrm{MPa}$ experiments. The composition of the experimental amphiboles is reported in the Electronic Appendix. $A=$ alkaline field; $C A=c a l c-a l k a l i n e$ field. 
(a)

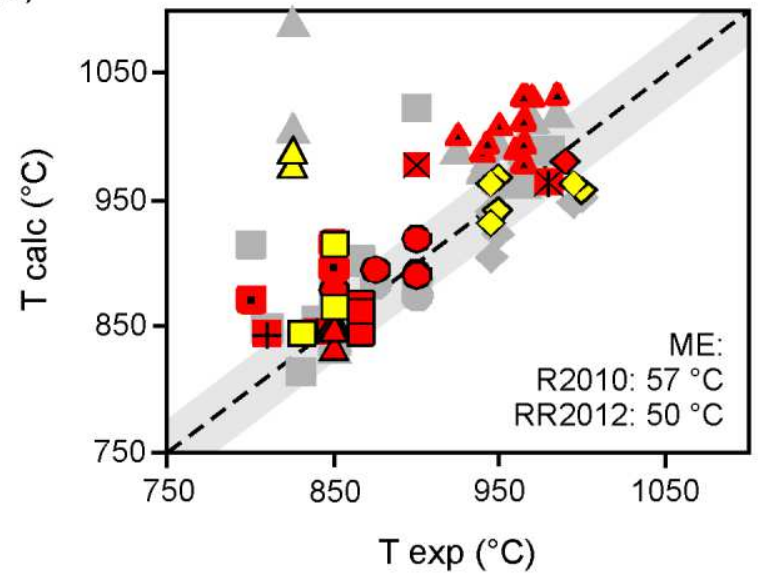

(c)

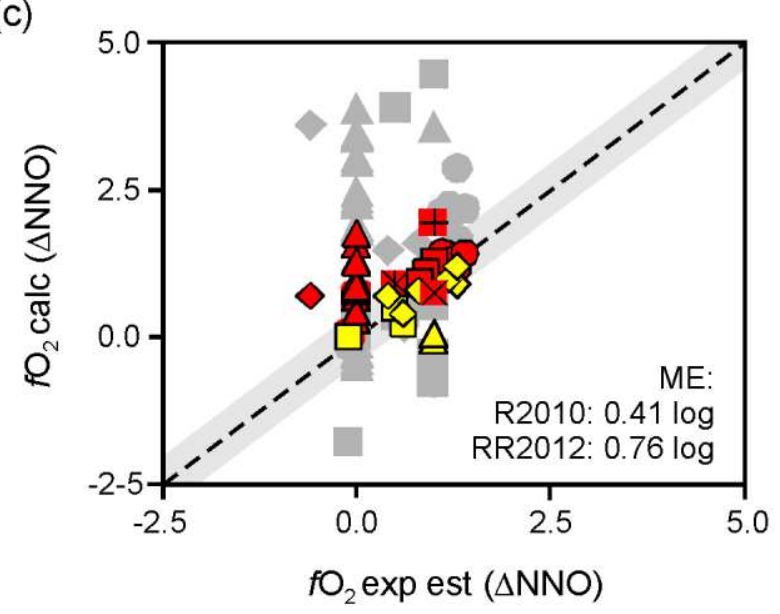

(e)

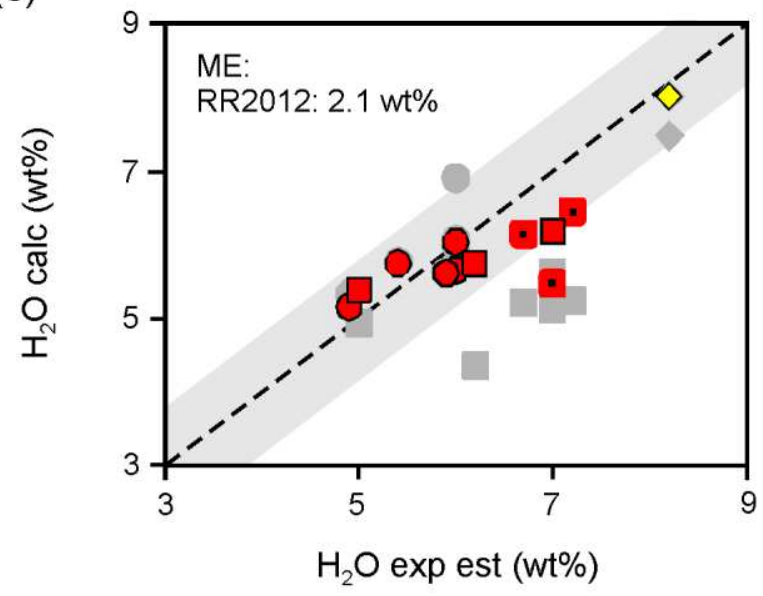

(b)

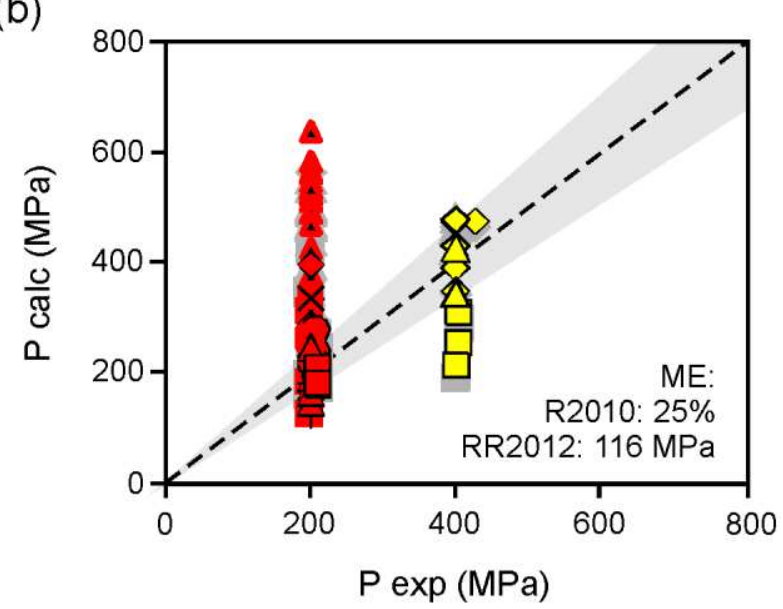

(d)

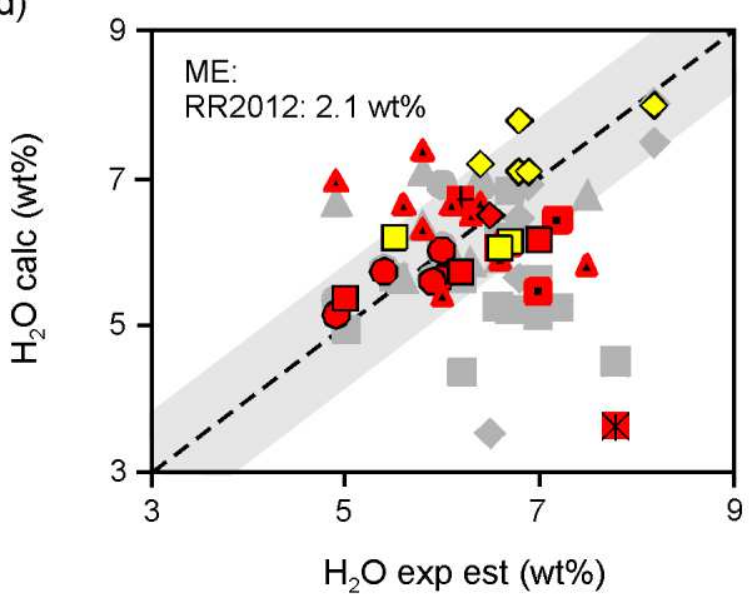

(f)

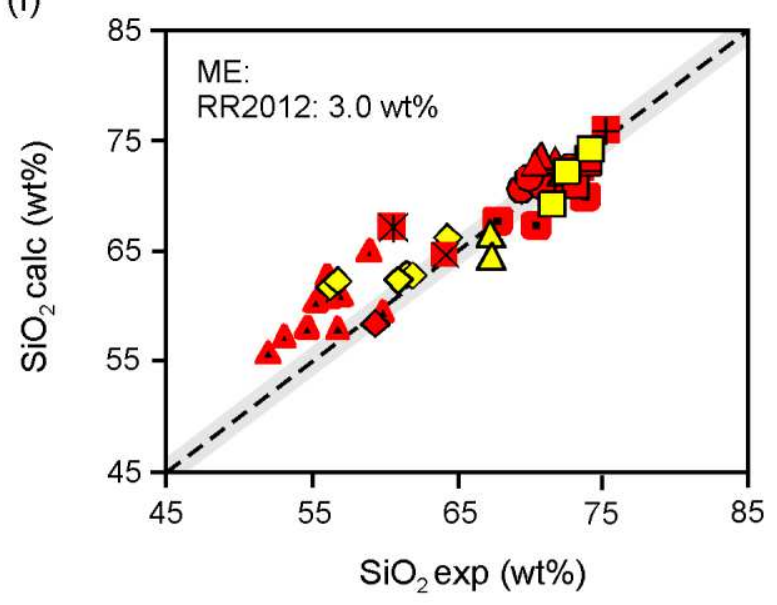

W Barclay \& Carmichael 2004

$\square \quad$ Bogaerts et al. 2006

- Costa et al. 2004

$\diamond$ Grove et al. 2003
Х Martel et al. 2013

$\triangle \Delta$ Martel et al. 2013

$\diamond$ Pichavant et al. 2002

- Pietranik et al. 2009
Rutherford \& Devine 2003

$\triangle \Delta$ Sato et al. 2005

$\square \quad$ Scaillet \& Evans 1999

A $\Delta$ Sisson \& Grove 1992

Figure 3 - Erdmann et al. 
Figure 3: Variation of calculated versus experimental crystallization conditions for (a) temperature; (b) pressure; (c) $f \mathrm{O}_{2}$; (d,e) melt $\mathrm{H}_{2} \mathrm{O}$ content; and (f) melt $\mathrm{SiO}_{2}$ content calculated using the $\mathrm{R} 2010$ calibration (red and yellow symbols) and the RR2012 calibration (grey symbols). Red symbols are for amphibole from $200 \mathrm{MPa}$ experiments; yellow symbols are for amphibole from $400 \mathrm{MPa}$ experiments. The calculated and experimental crystallization conditions are reported in Table 2 and in the Electronic Appendix. Grey fields indicate estimated standard errors ( $\sigma e s t)$; inset numbers give maximum errors (ME) reported by R2010 and RR2012.

(a)

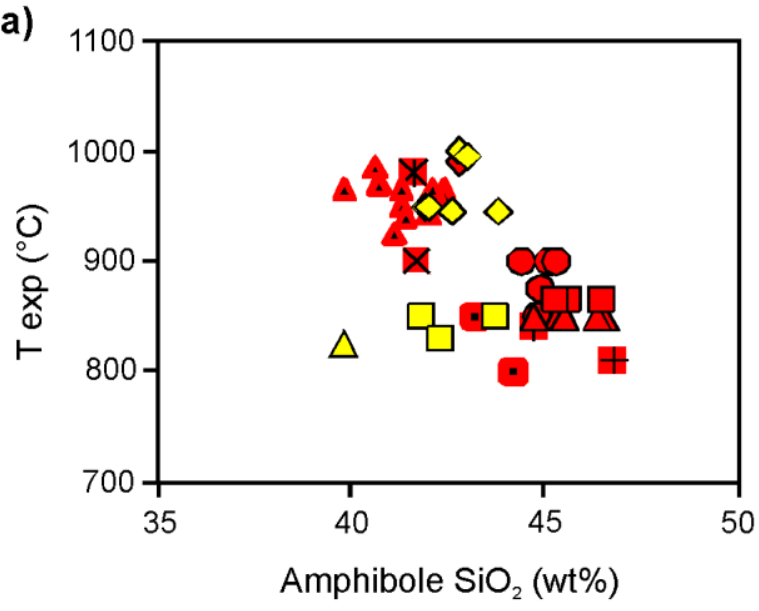

(c)

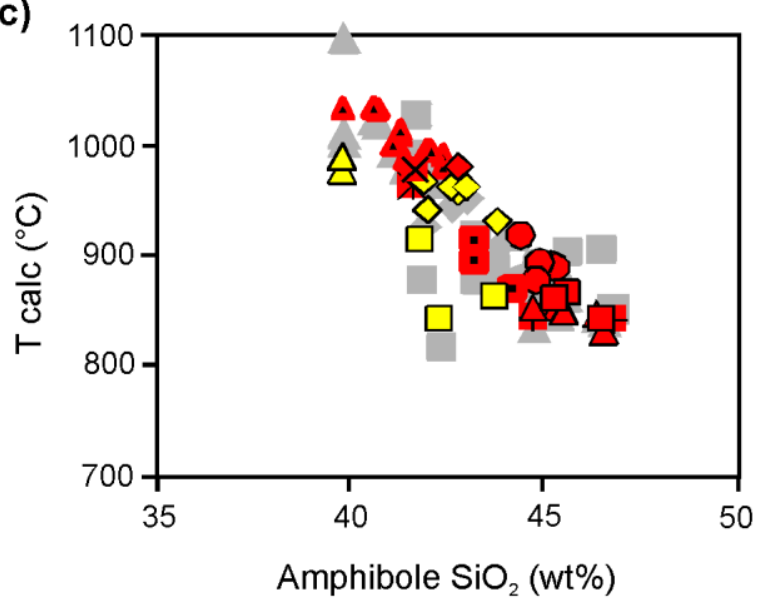

(b)

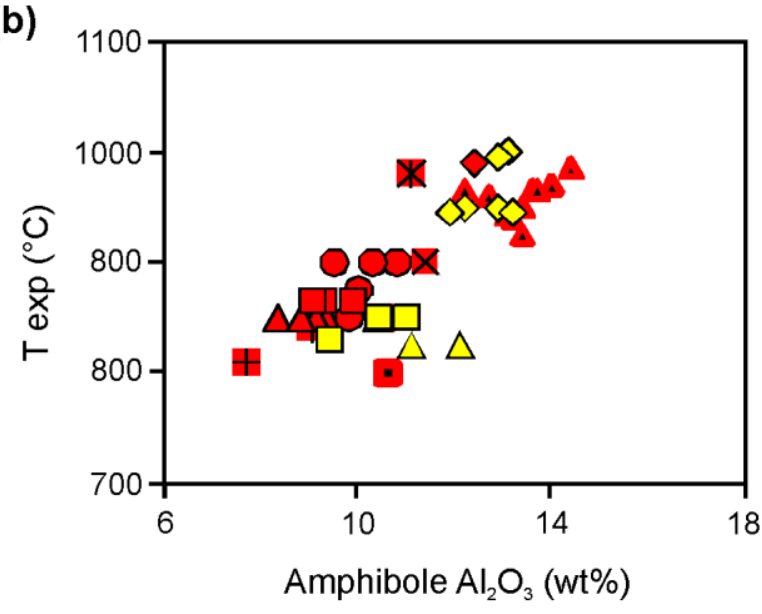

(d)

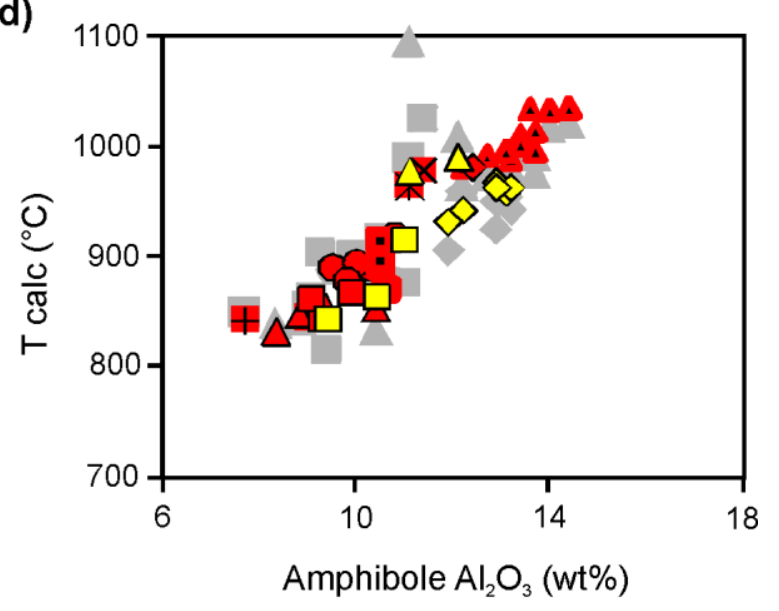

Figure 4 - Erdmann et al. 
Figure 4: Experimental $(a, b)$ and calculated $(c, d)$ temperatures compared to amphibole composition. Red symbols are for amphibole from 200 MPa experiments; yellow symbols are for amphibole from $400 \mathrm{MPa}$ experiments. The calculated and experimental crystallization temperatures are reported in Table 2 and in the Electronic Appendix. Symbols for the different experimental studies are those summarized in Figures 2 and 3. Values are reported in Table 2.

(a)

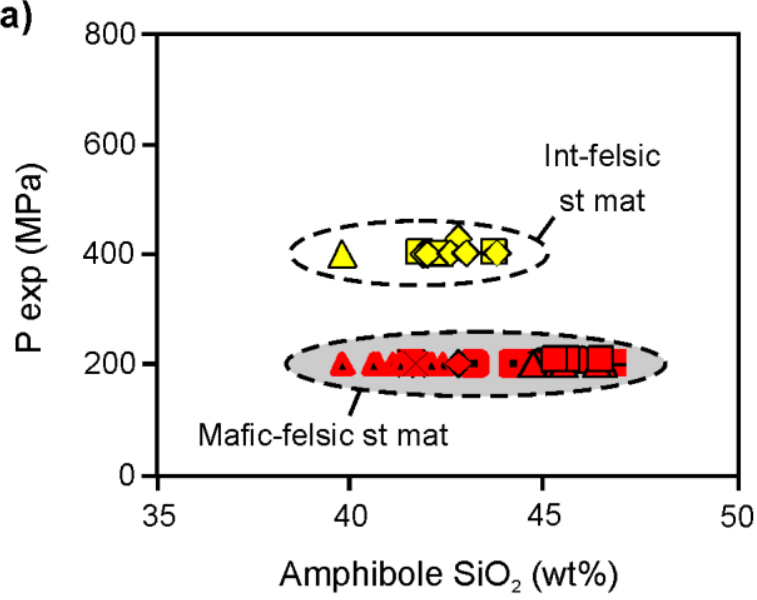

(c)

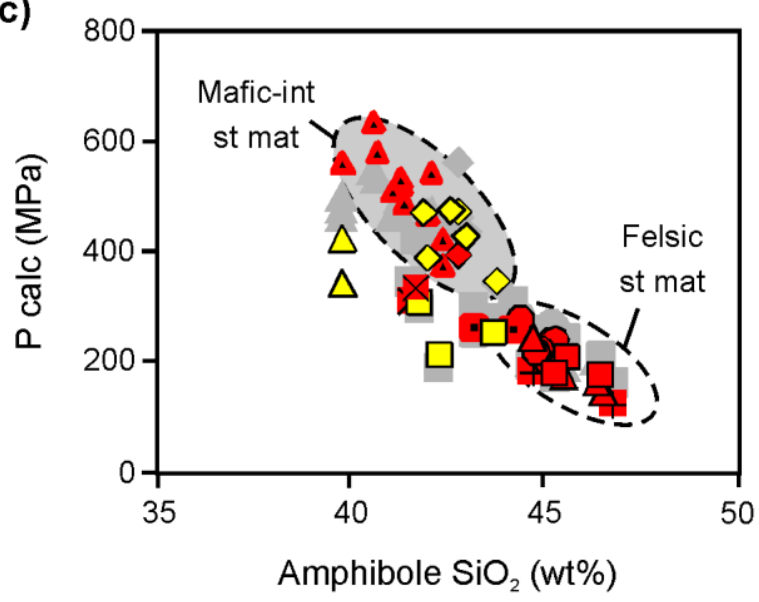

(b)

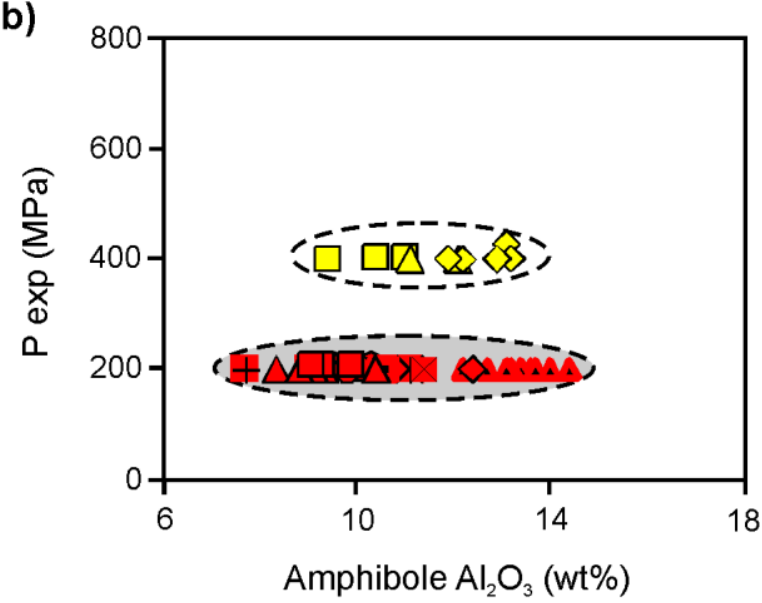

(d)

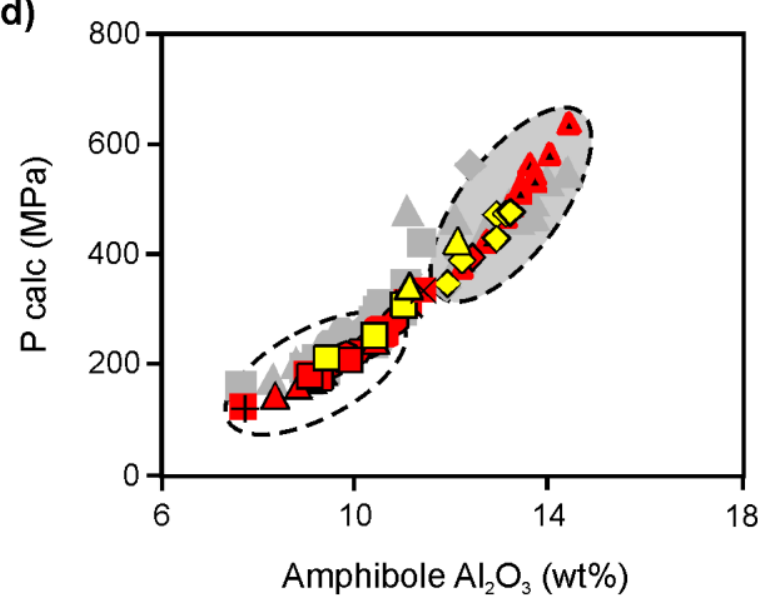

Figure 5 - Erdmann et al.

Figure 5: Experimental $(a, b)$ and calculated $(c, d)$ pressure values compared to amphibole and starting material (st mat) compositions. Red symbols signify amphibole from $200 \mathrm{MPa}$ experiments; yellow symbols signify amphibole from $400 \mathrm{MPa}$ experiments. The calculated and experimental crystallization pressures are reported in Table 2 and in the Electronic Appendix. Symbols for the 
different experimental studies are those summarized in Figures 2 and 3 . Int=intermediate compositions. Values are reported in Table 2.
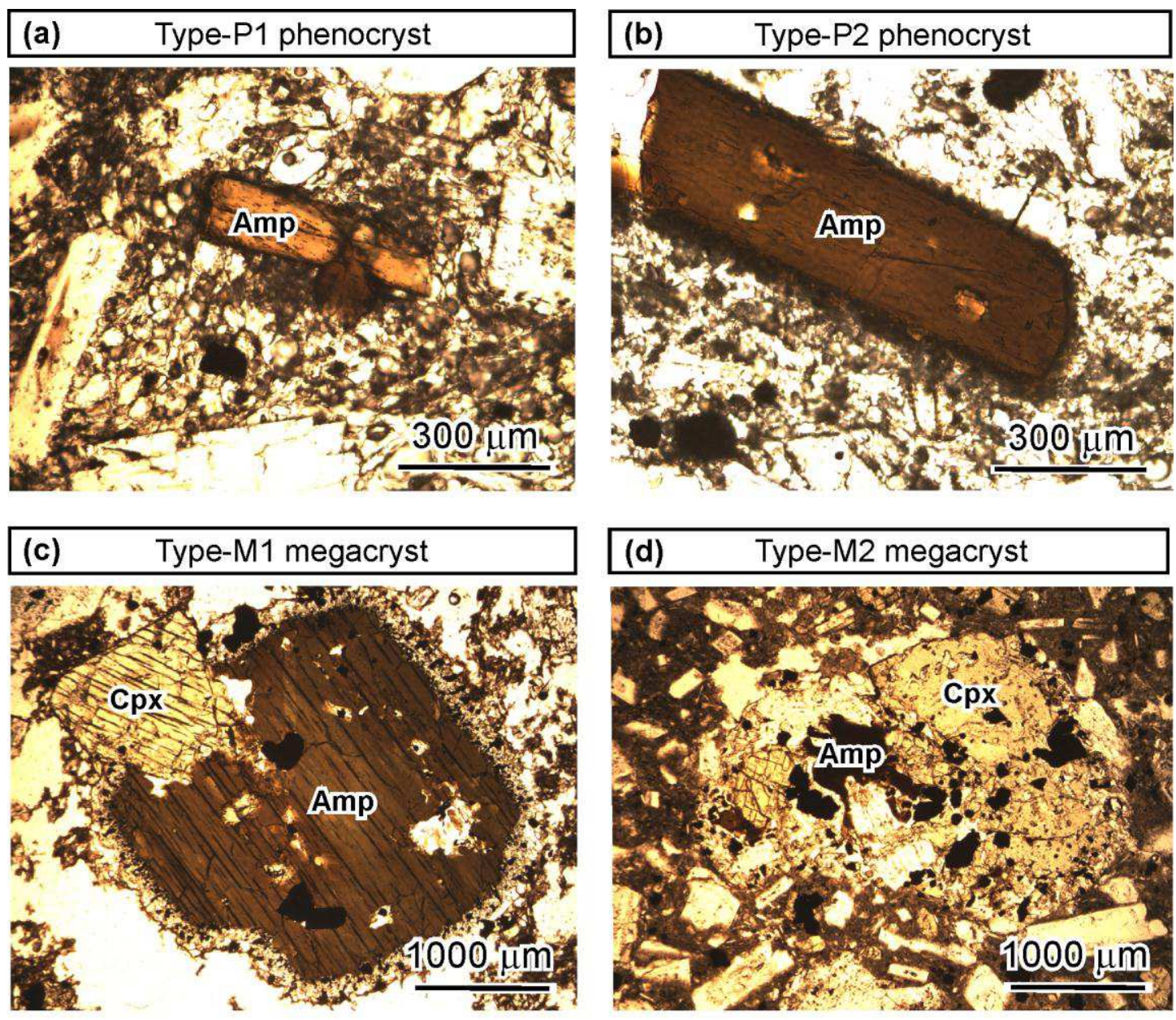

Figure 6 - Erdmann et al.

Figure 6: Transmitted light images of amphibole phenocrysts (a,b) and megacrysts (c,d) from pyroclasts erupted at Merapi in 2010. Amp=amphibole; $\mathrm{Cpx}=$ clinopyroxene. 

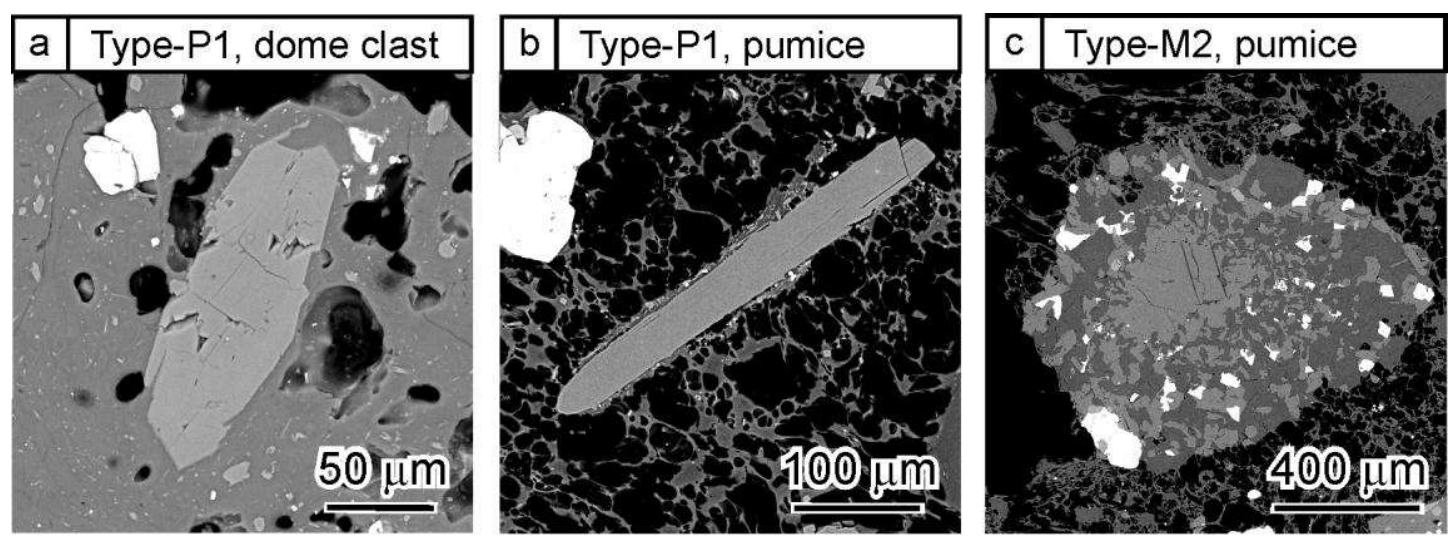

Figure 7 - Erdmann et al.

Figure 7: Back-scattered electron microscope images of amphibole phenocrysts and megacrysts. (a) Amphibole phenocrysts in the 2010 dome pyroclasts show no reaction rims. (b) Amphibole phenocrysts in the 2010 pumice samples show $<10 \mu \mathrm{m}$ wide reaction rims of pyroxene \pm plagioclase \pm oxide and glass. (c) Type-M1 amphibole megacrysts (not shown) and TypeM2 megacrysts have $>300 \mu \mathrm{m}$ wide, glass-free reaction rims consisting of subhedral plagioclase, clinopyroxene, oxide, and orthopyroxene. 
Megacrysts: $\Delta$ Type-M1 $\Delta$ Type-M2 Phenocrysts: $\square$ Type-P1 $\square$ Type-P2
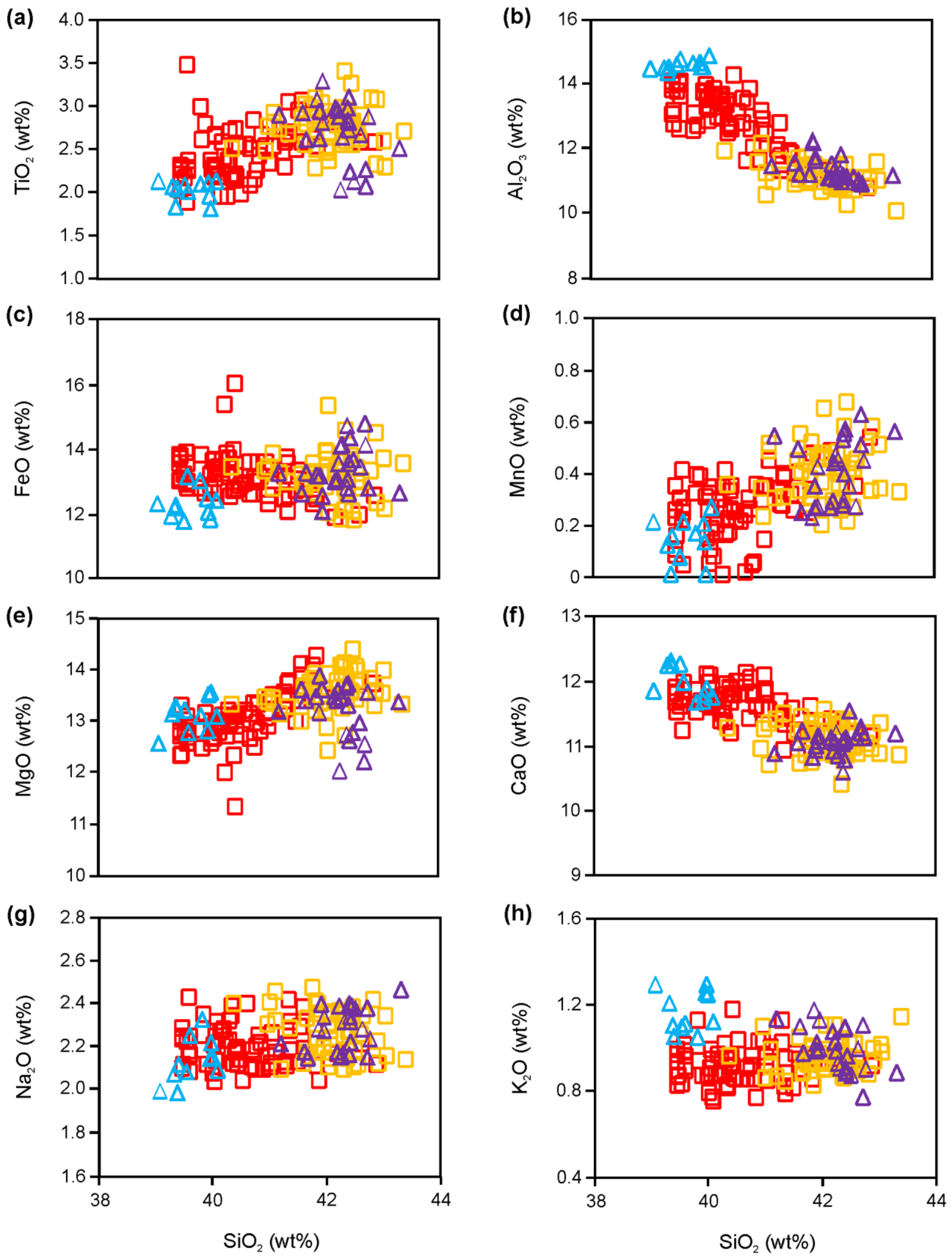

Figure 8 - Erdmann et al. 
Figure 8: Composition of amphibole phenocrysts and megacrysts in Merapi pyroclasts. All oxide concentrations are shown relative to $\mathrm{SiO}_{2}$. Concentrations of $\mathrm{Al}_{2} \mathrm{O}_{3}$ and $\mathrm{CaO}$ decrease and $\mathrm{TiO}_{2}$, $\mathrm{MnO}$, and $\mathrm{MgO}$ increase with increasing $\mathrm{SiO}_{2}$. Concentrations of $\mathrm{FeO}, \mathrm{Na}_{2} \mathrm{O}$, and $\mathrm{K}_{2} \mathrm{O}$ are relatively invariant with variations in amphibole $\mathrm{SiO}_{2}$ content. The Type-P1 phenocrysts show a large compositional range, while compositions of Type-P2 phenocrysts and megacrysts are clustered.

(a)
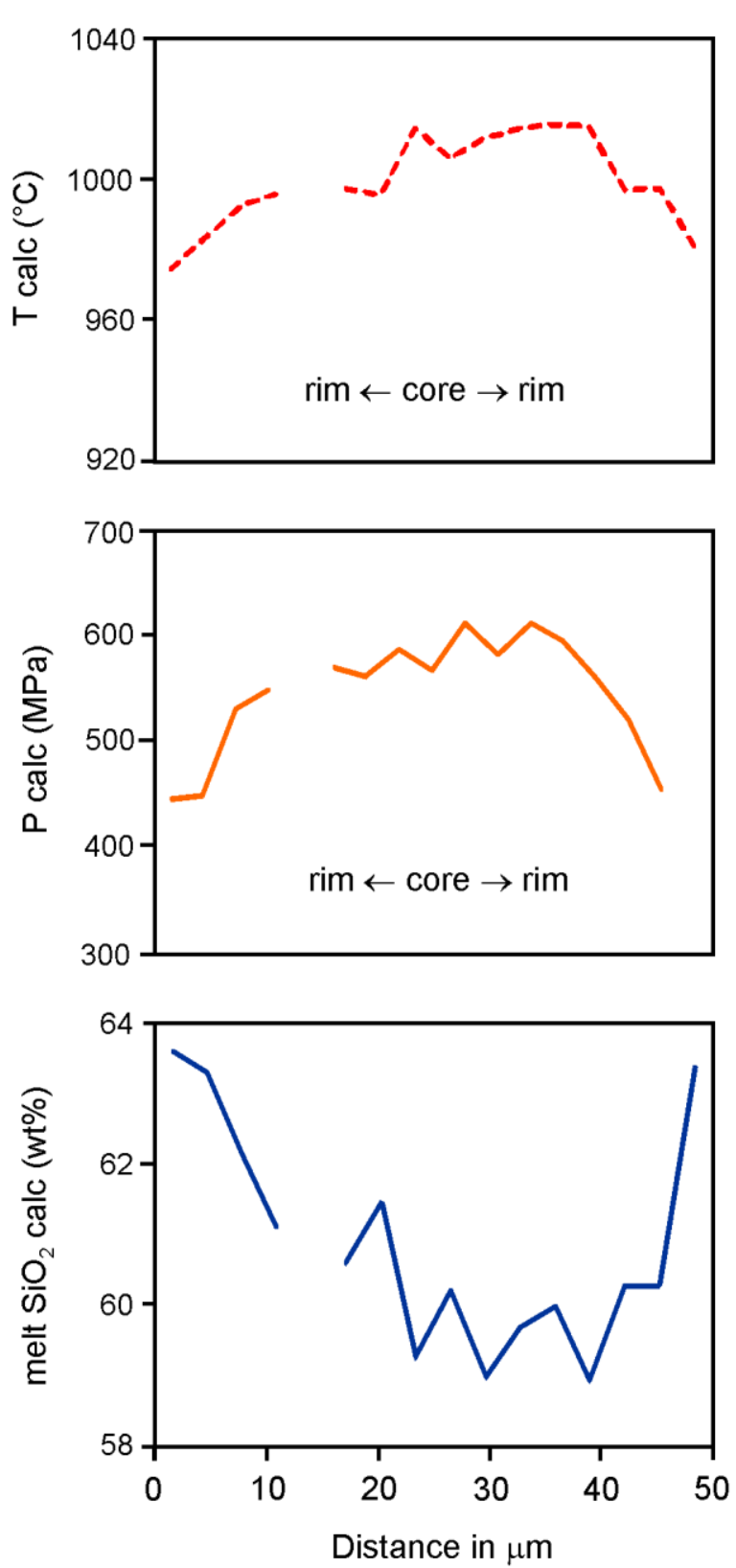

(b)

Type-P2 phenocryst
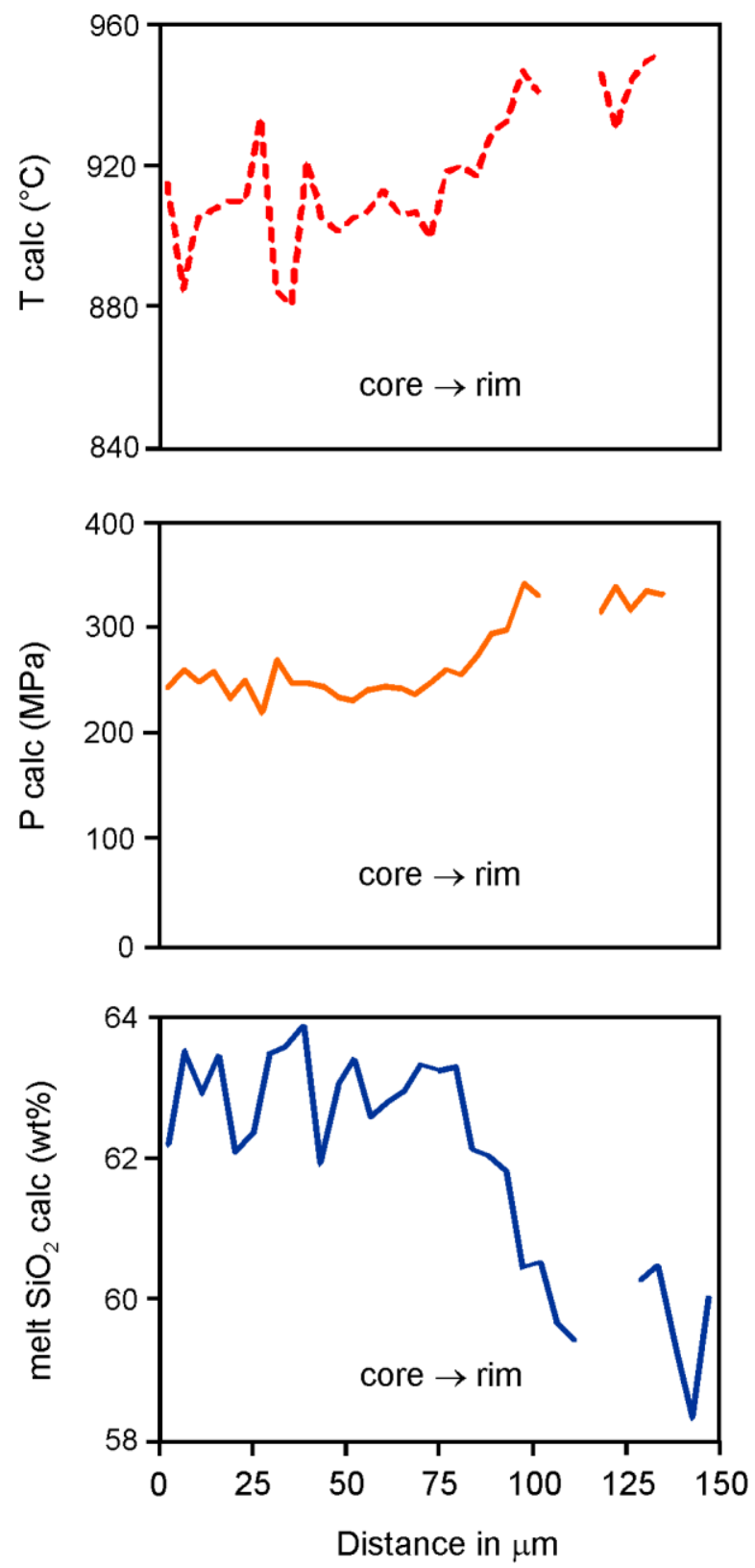

Figure 10 - Erdmann et al. 
Figure 9: Calculated crystallization conditions for Merapi amphibole phenocrysts and macrocrysts for: (a) pressure-temperature, (b) $f \mathrm{O}_{2}$-temperature, (c) melt $\mathrm{H}_{2} \mathrm{O}$ content-temperature, and (d) melt $\mathrm{SiO}_{2}$ content-temperature. Table 4 reports average, maximum, and minimum oxide concentrations of amphibole and calculated crystallization conditions. The large range of compositions determined for Type-P1 phenocrysts translates into a large range of calculated crystallization conditions. Crystallization conditions calculated for evolved Type-P1 phenocrysts, Type-P2 phenocrysts, and Type-M2 phenocrysts overlap. Those calculated for the Type-M1 megacrysts are offset to higher temperature and pressure compared to the other amphibole types. 
(a)
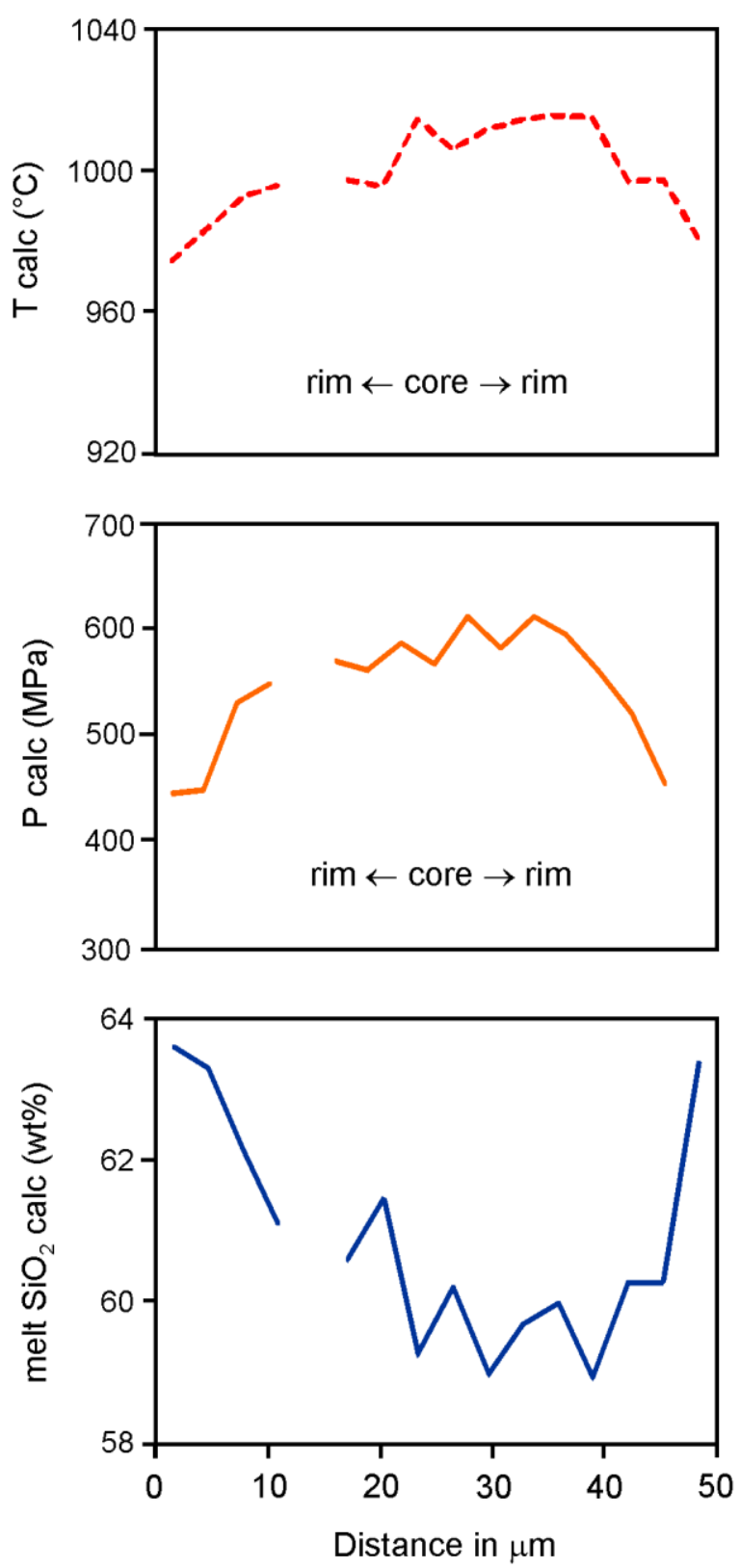

(b)

Type-P2 phenocryst
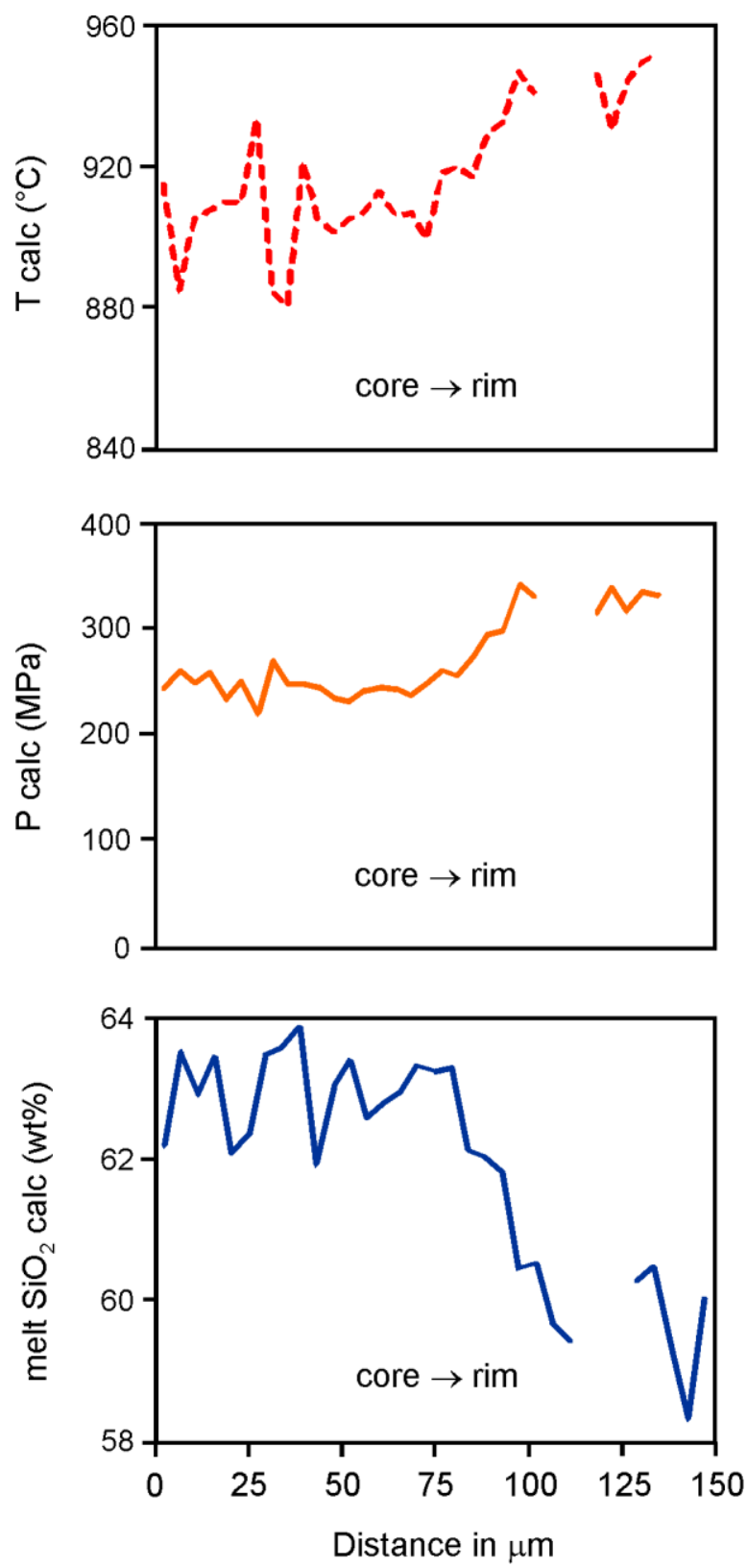

Figure 10 - Erdmann et al.

Figure 10: Variations in temperature, pressure, and melt $\mathrm{SiO}_{2}$ content for core-rim compositional zoning of (a) Type-P1 phenocrysts and (b) Type-P2 phenocrysts, calculated using the R2010 calibration. (a) The Type-P1 phenocrysts exhibit normal core-rim zoning with a rim-ward decrease in calculated temperature and pressure and an increase in calculated melt $\mathrm{SiO}_{2}$. (b) The Type-P2 
phenocrysts show weak oscillatory zoning and reverse core-rim zoning with an apparent rim-ward increase in calculated temperature and pressure and a decrease in calculated melt $\mathrm{SiO}_{2}$.

(a) Type-P1 / M1

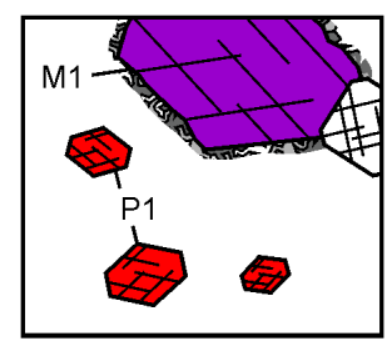

Recharge magma (b) Type-P1 / M1

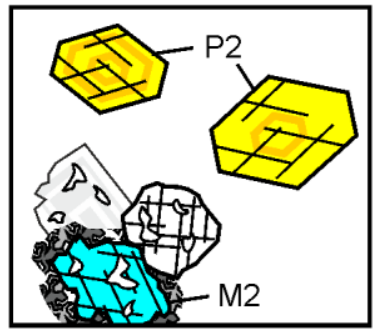

Resident magma (c)

Type-P1 and P2 / M1 and M2

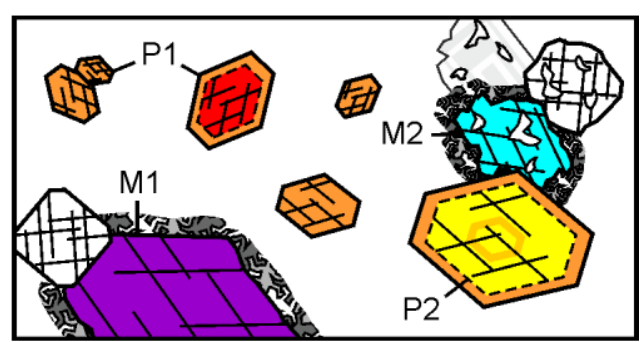

Mixed recharge and resident magmas (d) Time 1

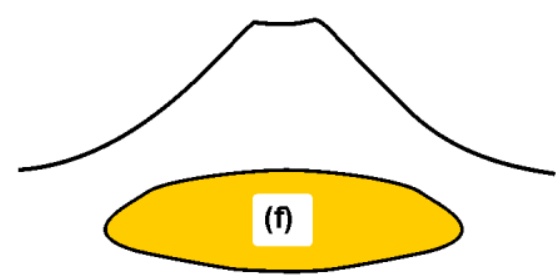

(e)

Recharge magma:

$\mathrm{T} \geq 980^{\circ} \mathrm{C}$

$\mathrm{fO}_{2} \geq \mathrm{NNO}+0.4$

Melt $\mathrm{SiO}_{2} \leq 60$ wt $\%$ (g) Time 2

(f)

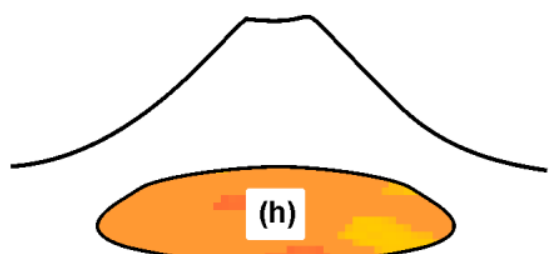

(h)

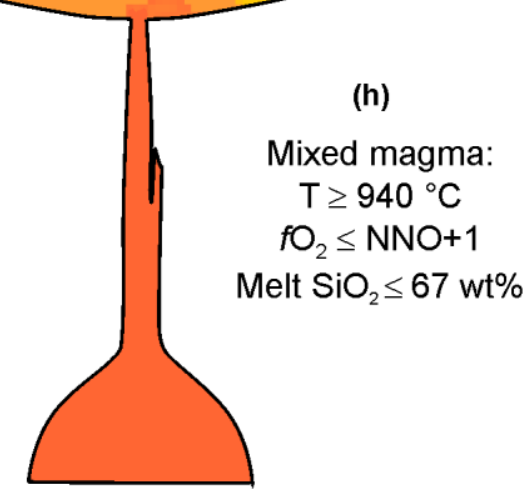

(e)

Resident magma:

$\mathrm{T} \geq 920^{\circ} \mathrm{C}$

$\mathrm{fO}_{2} \leq \mathrm{NNO}+1$

Melt $\mathrm{SiO}_{2} \leq 70$ wt $\%$
Mixed magma:

$\mathrm{T} \geq 940^{\circ} \mathrm{C}$

$\mathrm{fO}_{2} \leq \mathrm{NNO}+1$

Melt $\mathrm{SiO}_{2} \leq 67 \mathrm{wt} \%$

Figure 11 - Erdmann et al.

Figure 11: Schematic summary of amphibole types and their origin (a-c) in Merapi magmas and their estimated crystallization conditions (d-h). We infer that: (a) Type-P1 phenocrysts are cognate amphibole crystals that formed from recharge magma(s); Type-M1 megacrysts are xenocrysts derived from mafic cumulates. (b) Type-P2 phenocrysts are antecrysts derived from evolved resident magmas; and Type-M2 megacrysts are xenocrysts and/or antecrysts derived from relatively evolved, highly crystalline magma mush or completely crystallized pockets of evolved magma. (c) Type-P1 
crystals developed normal zoning and Type-P2 crystals developed reverse zoning as a result of mixing between recharge and resident magmas. (d,e) The recharge magma is inferred to have been relatively mafic, relatively reduced, and $\geq 980{ }^{\circ} \mathrm{C}$ hot. (d,f) The resident magma is inferred to have been evolved, relatively oxidized, and relatively cold. $(\mathrm{g}, \mathrm{h})$ Mixing is inferred to have driven magmas towards temperatures of $\geq 940{ }^{\circ} \mathrm{C}$, moderately oxidized conditions $f \mathrm{O}_{2}$ of $\leq \mathrm{NNO}+1$, and relatively mafic dacitic melt $\mathrm{SiO}_{2}$ contents. 
Table 1: Summary of thermobarometric and chemometric equations used in this study

\begin{tabular}{|c|c|c|}
\hline Reference & Variable & Equation \\
\hline \multirow[t]{4}{*}{ R2010 } & Temperature & $\begin{array}{l}\mathrm{T}\left({ }^{\circ} \mathrm{C}\right)=-151.487 \mathrm{Si}^{*}+2041 ; \mathrm{Si}^{*}=\mathrm{Si}+\left({ }^{[4]} \mathrm{Al} / 15\right)-\left(2^{[4]} \mathrm{Ti}\right)-\left({ }^{[6]} \mathrm{Al} / 2\right)- \\
\left({ }^{[6]} \mathrm{Ti} / 1.8\right)+\left(\mathrm{Fe}^{3+} / 9\right)+\left(\mathrm{Fe}^{2+} / 3.3\right)+(\mathrm{Mg} / 26)+\left({ }^{\mathrm{B}} \mathrm{Ca} / 5\right)+\left({ }^{\mathrm{B}} \mathrm{Na} / 1.3\right)-\left({ }^{\mathrm{A}} \mathrm{Na} / 15\right)+\left({ }^{\mathrm{A}}[\mathrm{]} / 2.3)\right.\end{array}$ \\
\hline & Oxygen fugacity & $\begin{array}{l}\Delta \text { NNO (log units })=1.644 \mathrm{Mg}^{*}-4.01 ; \mathrm{Mg}^{*}=\mathrm{Mg}+(\mathrm{Si} / 47)-\left({ }^{[6]} \mathrm{Al} / 9\right)- \\
\left(1.3^{[6]} \mathrm{Ti}\right)+\left(\mathrm{Fe}^{3+} / 3.7\right)+\left(\mathrm{Fe}^{2+} / 5.2\right)-\left({ }^{\mathrm{B}} \mathrm{Ca} / 20\right)-\left({ }^{\mathrm{A}} \mathrm{Na} / 2.8\right)+\left({ }^{\mathrm{A}}[\mathrm{]} / \mathrm{9} .5)\right.\end{array}$ \\
\hline & Melt $\mathrm{H}_{2} \mathrm{O}$ & $\begin{array}{l}\mathrm{H}_{2} \mathrm{O} \text { melt }(w t \%)=5.215^{[6]} \mathrm{Al}^{*}+12.28 ;{ }^{[6]} \mathrm{Al}^{*}={ }^{[6]} \mathrm{Al}+\left({ }^{[4]} \mathrm{Al} / 13.9\right)-\left(\left(\mathrm{Si}+{ }^{[6]} \mathrm{Ti}\right) / 5\right)- \\
\left.\left({ }^{\mathrm{C}} \mathrm{Fe}^{2+} / 3\right)-(\mathrm{Mg} / 1.7)+\left(\left({ }^{\mathrm{B}} \mathrm{Ca}+{ }^{\mathrm{A}}[]\right) / 1.2\right)\right)+\left({ }^{\mathrm{A}} \mathrm{Na} / 2.7\right)-1.56 \mathrm{~K}-(\mathrm{Fe \#} / 1.6)\end{array}$ \\
\hline & Pressure & $\mathrm{P}(\mathrm{MPa})=19.209 e^{(1.438 \mathrm{Altot})}$ \\
\hline \multirow[t]{6}{*}{ RR2012 } & Pressure (Eq 1b) & $\begin{array}{l}\mathrm{InP}(\mathrm{MPa})=38.723-2.6957 * \mathrm{Si}-2.3565^{*} \mathrm{Ti}-1.3006 * \mathrm{Al}-2.7780 * \mathrm{Fe}-2.4838^{*} \mathrm{Mg} \\
-0.6614^{*} \mathrm{Ca}-0.2705^{*} \mathrm{Na}+0.1117 * \mathrm{~K}\end{array}$ \\
\hline & Pressure (Eq 1c) & $\begin{array}{l}\mathrm{P}(\mathrm{MPa})=24,023-1,925.3 * \mathrm{Si}-1,720.6 * \mathrm{Ti}-1,478.5 * \mathrm{Al}-1,843.2 * \mathrm{Fe}-1,746.9 * \mathrm{Mg} \\
-158.28 * \mathrm{Ca}-40.444 * \mathrm{Na}+253.52 * \mathrm{~K}\end{array}$ \\
\hline & Temperature & $\begin{array}{l}\mathrm{T}\left({ }^{\circ} \mathrm{C}\right)=17,098-1,322.3 * \mathrm{Si}-1,035.1 * \mathrm{Ti}-1,208.2 * \mathrm{Al}-1,230.4 * \mathrm{Fe}-1,152.9 * \mathrm{Mg}- \\
130.40 * \mathrm{Ca}+200.54 * \mathrm{Na}+29.408 * \mathrm{~K}+24.410 * \ln \mathrm{P}\end{array}$ \\
\hline & Oxygen fugacity & $\begin{array}{l}\Delta \mathrm{NNO}(\mathrm{log} \text { units })=214.39-17.042 * \mathrm{Si}-26.080 * \mathrm{Ti}-16.389 * \mathrm{Al}-18.397 * \mathrm{Fe}- \\
15.152 * \mathrm{Mg}+0.2162 * \mathrm{Ca}+6.1987 * \mathrm{Na}+14.389 * \mathrm{~K}\end{array}$ \\
\hline & Melt $\mathrm{H}_{2} \mathrm{O}$ & $\begin{array}{l}\text { InH } \mathrm{H}_{2} \mathrm{O} \text { melt }(w t \%)=-65.907+5.0981 * \mathrm{Si}+3.1308 * \mathrm{Ti}+4.9211 * \mathrm{Al}+4.9744 * \mathrm{Fe} \\
+4.6536 * \mathrm{Mg}+1.0018 * \mathrm{Ca}-0.7890 * \mathrm{Na}-0.539 * \mathrm{~K}+0.4642 * \ln \mathrm{P}\end{array}$ \\
\hline & $\mathrm{MeltSiO}_{2}$ & $\begin{array}{l}\mathrm{SiO}_{2}(w \mathrm{t} \%)=-142.31+22.008 * \mathrm{Si}-15.306 * \mathrm{Ti}+2.1880 * \mathrm{Al}+16.455^{*} \mathrm{Fe} \\
+12.868 * \mathrm{Mg}+0.4085^{*} \mathrm{Ca}+6.7100 * \mathrm{Na}+20.980 * \mathrm{~K}-9.6423 * 10^{8} \mathrm{P}^{-4}\end{array}$ \\
\hline
\end{tabular}

R2010 = Ridolfi et al. (2010); RR2012 = Ridolfi and Renzulli (2012) 


\begin{tabular}{|c|c|c|c|c|c|c|c|c|c|c|c|c|c|c|c|c|c|c|}
\hline \multirow{2}{*}{$\begin{array}{l}\text { Studies, } \\
\text { St mat, } \\
\text { Exp }\end{array}$} & \multicolumn{4}{|c|}{ Amphibole composition (wt\%) } & \multicolumn{3}{|c|}{$\begin{array}{l}\text { Temperature } \\
\left({ }^{\circ} \mathrm{C}\right)\end{array}$} & \multicolumn{3}{|c|}{ Pressure (MPa) } & \multicolumn{3}{|c|}{$\log f \mathrm{O}_{2}(\Delta \mathrm{NNO})$} & \multicolumn{3}{|c|}{ Melt $\mathrm{H}_{2} \mathrm{O}$ (wt\%) } & \multicolumn{2}{|c|}{$\begin{array}{c}\text { Melt } \mathrm{SiO}_{2} \\
\quad \text { (wt\%) }\end{array}$} \\
\hline & $\mathrm{SiO}_{2}$ & $\mathrm{Al}_{2} \mathrm{O}_{3}$ & $\mathrm{TiO}_{2}$ & $\mathrm{X}_{\mathrm{Mg}}{ }^{* *}$ & $\operatorname{Exp}$ & R10 & RR12 & $\operatorname{Exp}$ & R10 & *RR12 & $\operatorname{Exp}$ & R10 & RR12 & Exp & R10 & RR12 & Exp & RR12 \\
\hline \multicolumn{19}{|c|}{ Barclay and Carmichael 2004 - Trachybasalt crystallization } \\
\hline Jor46.44 & 41.6 & 11.1 & 2.6 & 0.69 & 980 & 963 & 988 & 200 & 312 & 342 & 0.5 & 0.9 & 3.9 & $7.8^{d}$ & 3.6 & 4.5 & 60.8 & 67.1 \\
\hline \multicolumn{19}{|c|}{ Bogaerts et al. 2006 - Granodiorite crystallization } \\
\hline $50-9$ & 41.8 & 11.0 & 2.1 & 0.54 & 850 & 914 & 876 & 404 & 310 & 296 & 0.6 & 0.2 & 0.4 & $6.7^{\mathrm{e}}$ & 6.1 & 6.8 & 71.8 & 69.2 \\
\hline $50-10^{b}$ & 43.7 & 10.4 & 2.0 & 0.54 & 850 & 863 & 886 & 404 & 255 & 281 & 0.5 & 0.5 & 0.4 & $5.5^{\mathrm{e}}$ & 6.2 & 5.6 & 72.7 & 72.2 \\
\hline $50-26^{b}$ & 42.3 & 9.4 & 2.0 & 0.44 & 830 & 843 & 814 & 399 & 213 & 187 & 0.1 & 0.0 & -1.8 & $6.6^{\mathrm{e}}$ & 6.0 & 6.2 & 74.4 & 74.3 \\
\hline \multicolumn{19}{|c|}{ Costa et al. 2004 - Dacite crystallization } \\
\hline 8 & 44.4 & 10.8 & 1.6 & 0.72 & 900 & 918 & 876 & 206 & 278 & 282 & 1.3 & 1.2 & 2.9 & $6.0^{f}$ & 6.0 & 6.9 & 69.6 & 70.6 \\
\hline 9 & 45.2 & 10.3 & 1.9 & 0.72 & 900 & 891 & 888 & 206 & 237 & 269 & 1.2 & 1.4 & 2.2 & $5.4^{f}$ & 5.7 & 5.7 & 71.0 & 70.9 \\
\hline 10 & 45.1 & 9.5 & 2.1 & 0.74 & 900 & 890 & 887 & 206 & 201 & 235 & 1.1 & 1.4 & 2.1 & $4.9^{f}$ & 5.1 & 5.3 & 72.2 & 71.2 \\
\hline 47 & 45.3 & 10.3 & 1.9 & 0.69 & 900 & 889 & 873 & 206 & 239 & 259 & 1.3 & 1.2 & 1.7 & $6.0^{f}$ & 6.0 & 6.1 & 71.0 & 70.9 \\
\hline 97 & 44.9 & 10.0 & 1.7 & 0.70 & 875 & 894 & 883 & 203 & 223 & 248 & 1.2 & 1.3 & 2.1 & $6.0^{f}$ & 5.6 & 6.0 & 70.1 & 71.6 \\
\hline $94^{b}$ & 44.8 & 9.8 & 1.6 & 0.69 & 850 & 878 & 891 & 200 & 218 & 257 & 1.4 & 1.4 & 2.2 & $5.9^{f}$ & 5.6 & 5.6 & 72.9 & 72.6 \\
\hline \multicolumn{19}{|c|}{ Grove et al. 2003 - Magnesian andesite crystallization } \\
\hline $85-44 \# 5$ & 42.8 & 12.4 & 3.1 & 0.75 & 990 & 980 & 1124 & 200 & 395 & 561 & 0.6 & 0.7 & 3.6 & $6.5^{\mathrm{d}}$ & 6.5 & 3.5 & 59.5 & 58.4 \\
\hline \multicolumn{19}{|c|}{ Martel et al. 2013 - Trachyte crystallization } \\
\hline 825VAS4 & 39.8 & 11.1 & 2.7 & 0.59 & 825 & 977 & 1093 & 400 & 343 & 478 & 1 & 0.0 & 5.2 & - & 3.6 & 3.7 & 67.4 & 66.6 \\
\hline $825 C L I 4$ & 39.8 & 12.1 & 2.5 & 0.59 & 825 & 989 & 1008 & 400 & 426 & 462 & 1 & 0.1 & 3.6 & - & 4.8 & 5.4 & 67.5 & 64.5 \\
\hline 900CLI2 & 41.7 & 11.4 & 2.9 & 0.73 & 900 & 977 & 1024 & 200 & 335 & 419 & 1 & 0.8 & 4.5 & - & 4.0 & 4.3 & 64.4 & 64.6 \\
\hline \multicolumn{19}{|c|}{ Pichavant et al. 2002 - Basaltic andesite crystallization } \\
\hline Hab1 & 41.9 & 12.9 & 1.8 & 0.66 & 949 & 967 & 923 & 399 & 472 & 431 & 0.8 & 0.8 & 1.6 & $8.2^{g}$ & 8.0 & 8.0 & 61.7 & 62.9 \\
\hline Hab2 & 42.0 & 12.2 & 2.7 & 0.59 & 949 & 941 & 958 & 399 & 389 & 395 & 0.6 & 0.4 & 0.2 & $6.8^{e}$ & 7.1 & 5.6 & 62.1 & 62.8 \\
\hline Hab7 & 42.8 & 13.1 & 2.3 & 0.68 & 1000 & 957 & 952 & 427 & 474 & 462 & 0.4 & 0.7 & 1.5 & $6.8^{e}$ & 7.8 & 6.4 & 56.4 & 61.8 \\
\hline Hab11 & 42.6 & 13.2 & 1.9 & 0.66 & 945 & 962 & 941 & 400 & 477 & 462 & 1.3 & 0.9 & 1.5 & $8.2^{g}$ & 8.0 & 7.5 & 61.1 & 62.4 \\
\hline Hab12 & 43.8 & 11.9 & 1.9 & 0.67 & 945 & 931 & 905 & 400 & 347 & 341 & 1.2 & 1.0 & 1.3 & $6.9^{\mathrm{e}}$ & 7.1 & 6.9 & 64.5 & 66.2 \\
\hline Hab14 & 43.0 & 12.9 & 2.0 & 0.70 & 995 & 962 & 948 & 400 & 429 & 434 & 1.3 & 1.2 & 1.7 & $6.4^{\mathrm{e}}$ & 7.2 & 6.8 & 56.9 & 62.3 \\
\hline \multicolumn{19}{|c|}{ Pietranik et al. 2009 - Quartz diorite crystallization } \\
\hline $850 / 1 / 2$ & 43.2 & 10.5 & 2.6 & 0.61 & 850 & 895 & 915 & 200 & 261 & 299 & 0.0 & 0.7 & 0.0 & $6.7^{e}$ & 6.1 & 5.2 & 70.6 & 67.3 \\
\hline $850 / 0.9 / 2$ & 43.2 & 10.5 & 3.1 & 0.58 & 850 & 915 & 875 & 200 & 263 & 251 & 0.1 & 0.1 & -0.1 & $7.0^{e}$ & 5.5 & 5.6 & 67.9 & 67.7 \\
\hline $800 / 1 / 2^{b}$ & 44.2 & 10.6 & 2.2 & 0.58 & 800 & 870 & 914 & 200 & 259 & 310 & 0.0 & 0.7 & 0.3 & $7.2^{\mathrm{e}}$ & 6.4 & 5.2 & 73.9 & 70.0 \\
\hline
\end{tabular}


Table 3: Characteristic textures of Merapi amphibole phenocrysts and megacrysts

\begin{tabular}{|c|c|c|c|c|}
\hline Crystal type & Phenocryst & Phenocryst & Megacryst & Megacryst \\
\hline Subtype & Type-P1 & Type-P2 & Type-M1 & Type-M2 \\
\hline Typical length & $<500 \mu \mathrm{m}$ & $<3 \mathrm{~mm}$ & $<2 \mathrm{~cm}$ & $<1 \mathrm{~cm}$ \\
\hline Crystal shape & Eu- to subhedral & Eu- to subhedral & Eu- to subhedral & Sub- to anhedral \\
\hline Occurence & Single crystals & Single crystals & $\begin{array}{l}\text { Single crystals or } \\
\text { crystal cluster }\end{array}$ & $\begin{array}{l}\text { Single crystals or crystal } \\
\text { cluster with resorbed } \\
\mathrm{PI}+\mathrm{Cpx}\end{array}$ \\
\hline Zoning & Normal & Unzoned-reverse & Patchy normal & Unzoned-reverse \\
\hline Reaction rim & $<10 \mu \mathrm{m}$ wide & $<10 \mu \mathrm{m}$ wide & $>300 \mu \mathrm{m}$ wide & $>300 \mu \mathrm{m}$ wide \\
\hline Inferred origin & Cognate magmatic & Antecryst & Xenocryst & Xenocryst/Antecryst \\
\hline
\end{tabular}


Table 4: Composition of Merapi amphibole (in wt\%) and their calculated crystallization conditions

\begin{tabular}{|c|c|c|c|c|c|c|c|c|c|c|c|c|}
\hline \multirow{3}{*}{$\begin{array}{l}\text { Crystal type } \\
\text { Subtype }\end{array}$} & \multirow{2}{*}{\multicolumn{3}{|c|}{$\begin{array}{c}\text { Phenocryst } \\
\text { Type-P1 }\end{array}$}} & \multirow{2}{*}{\multicolumn{3}{|c|}{$\begin{array}{l}\text { Phenocryst } \\
\text { Type-P2 }\end{array}$}} & \multirow{2}{*}{\multicolumn{3}{|c|}{$\begin{array}{c}\text { Megacryst } \\
\text { Type-M1 }\end{array}$}} & \multirow{2}{*}{\multicolumn{3}{|c|}{$\begin{array}{c}\text { Megacryst } \\
\text { Type-M2 }\end{array}$}} \\
\hline & & & & & & & & & & & & \\
\hline & $A v$ & Min & Max & Av & Min & Max & $A v$ & Min & Max & $A v$ & Min & Max \\
\hline \multirow[t]{2}{*}{$\mathrm{SiO}_{2}$} & 40.5 & 39.4 & 42.8 & 42.20 & 40.37 & 43.40 & 39.6 & 39.0 & 40.1 & 42.2 & 41.2 & 43.3 \\
\hline & 7 & 5 & 8 & & & & 5 & 7 & 0 & 7 & 0 & 3 \\
\hline $\mathrm{TiO}_{2}$ & 2.45 & 1.88 & 3.46 & 2.75 & 2.28 & 3.39 & 2.02 & 1.81 & 2.12 & 2.70 & 2.02 & 3.28 \\
\hline \multirow[t]{2}{*}{$\mathrm{Al}_{2} \mathrm{O}_{3}$} & 12.8 & 10.8 & 14.2 & 11.10 & 10.06 & 12.15 & 14.5 & 14.3 & 14.8 & 11.3 & 10.9 & 12.2 \\
\hline & 2 & 0 & 8 & & & & 8 & 6 & 7 & 3 & 1 & 7 \\
\hline $\mathrm{Cr}_{2} \mathrm{O}_{3}$ & 0.00 & 0.00 & 0.03 & 0.01 & 0.00 & 0.22 & 0.01 & 0.00 & 0.03 & 0.01 & 0.00 & 0.05 \\
\hline \multirow[t]{2}{*}{$\mathrm{FeO}$} & 13.1 & 11.8 & 15.9 & 13.10 & 11.76 & 15.28 & 12.2 & 11.7 & 13.1 & 13.3 & 12.0 & 14.7 \\
\hline & 1 & 5 & 9 & & & & 6 & 2 & 0 & 0 & 2 & 3 \\
\hline $\mathrm{MnO}$ & 0.26 & 0.00 & 0.54 & 0.39 & 0.19 & 0.67 & 0.13 & 0.00 & 0.26 & 0.40 & 0.22 & 0.62 \\
\hline \multirow[t]{2}{*}{$\mathrm{MgO}$} & 13.0 & 11.3 & 14.2 & 13.55 & 12.41 & 14.38 & 13.0 & 12.5 & 13.5 & 13.2 & 12.0 & 13.8 \\
\hline & 2 & 2 & 5 & & & & 9 & 4 & 3 & 2 & 2 & 6 \\
\hline \multirow[t]{2}{*}{$\mathrm{CaO}$} & 11.6 & 10.9 & 12.1 & 11.07 & 10.40 & 11.55 & 11.9 & 11.6 & 12.3 & 11.0 & 10.5 & 11.5 \\
\hline & 3 & 4 & 2 & & & & 6 & 6 & 0 & 5 & 8 & 3 \\
\hline $\mathrm{Na}_{2} \mathrm{O}$ & 2.20 & 2.04 & 2.43 & 2.27 & 2.09 & 2.48 & 2.13 & 1.98 & 2.33 & 2.28 & 2.15 & 2.46 \\
\hline $\mathrm{K}_{2} \mathrm{O}$ & 0.92 & 0.75 & 1.18 & 0.95 & 0.82 & 1.14 & 1.16 & 1.05 & 1.29 & 0.99 & 0.77 & 1.17 \\
\hline $\mathrm{F}$ & 0.17 & 0.00 & 0.68 & 0.23 & 0.00 & 0.53 & 0.31 & 0.00 & 0.63 & 0.22 & 0.00 & 0.58 \\
\hline \multirow[t]{2}{*}{ Total } & 97.1 & & & 97.54 & & & 97.3 & & & 97.8 & & \\
\hline & 7 & & & & & & 3 & & & & & \\
\hline
\end{tabular}

Calculated using the Ridolfi et al. (2010) calibration

\begin{tabular}{|c|c|c|c|c|c|c|c|c|c|c|c|c|}
\hline $\mathrm{T}\left({ }^{\circ} \mathrm{C}\right)$ & 991 & 931 & 1023 & 946 & 907 & 981 & 1033 & 1025 & 1041 & 944 & 923 & 965 \\
\hline $\mathrm{P}(\mathrm{MPa})$ & 486 & 279 & 665 & 305 & 234 & 392 & 733 & 705 & 756 & 320 & 286 & 394 \\
\hline $\mathrm{fO}_{2}(\Delta \mathrm{NNO})$ & 0.5 & 0.2 & 1.1 & 0.7 & 0.5 & 1.0 & 0.6 & 0.4 & 0.7 & 0.6 & 0.4 & 0.8 \\
\hline Melt $\mathrm{H}_{2} \mathrm{O}$ (wt\%) & 5.9 & 4.0 & 7.2 & 4.5 & 3.6 & 5.1 & 6.6 & 6.0 & 7.0 & 4.7 & 3.8 & 5.9 \\
\hline
\end{tabular}

Calculated using the Ridolfi and Renzulli (2012) calibration (average E1b and E1c)

\begin{tabular}{|c|c|c|c|c|c|c|c|c|c|c|c|c|}
\hline $\mathrm{T}\left({ }^{\circ} \mathrm{C}\right)$ & 960 & 899 & 1033 & 979 & 916 & 1028 & 948 & 908 & 971 & 976 & 931 & 1015 \\
\hline $\mathrm{P}(\mathrm{MPa})$ & 461 & 349 & 564 & 368 & 287 & 426 & 597 & 542 & 651 & 379 & 324 & 441 \\
\hline $\mathrm{fO}_{2}(\Delta \mathrm{NNO})$ & 2.4 & 1.6 & 3.3 & 2.5 & 1.7 & 3.2 & 3.5 & 3.1 & 4.2 & 2.6 & 2.1 & 3.2 \\
\hline Melt $\mathrm{H}_{2} \mathrm{O}$ (wt\%) & 6.8 & 4.2 & 9.2 & 4.7 & 3.9 & 6.0 & 8.9 & 8.0 & 10.5 & 4.9 & 4.2 & 6.1 \\
\hline Melt $\mathrm{SiO}_{2}(w \mathrm{t} \%)$ & 62 & 59 & 67 & 66 & 63 & 71 & 60 & 59 & 61 & 66 & 63 & 70 \\
\hline
\end{tabular}

